\title{
Temperate and boreal forest tree phenology: from organ-scale processes to terrestrial ecosystem models
}

\author{
Nicolas Delpierre $^{1} \cdot$ Yann Vitasse $^{2,3,4}$ - Isabelle Chuine ${ }^{5} \cdot$ Joannès Guillemot $^{1}$. \\ Stéphane Bazot $^{1}$ - This Rutishauser ${ }^{6}$ - Cyrille B. K. Rathgeber ${ }^{7}$
}

Received: 29 November 2014 / Accepted: 17 March 2015 / Published online: 24 April 2015

(C) The Author(s) 2015. This article is published with open access at Springerlink.com

\begin{abstract}
- Key message We demonstrate that, beyond leaf phenology, the phenological cycles of wood and fine roots present clear responses to environmental drivers in temperate and boreal trees. These drivers should be included in terrestrial ecosystem models.

- Context In temperate and boreal trees, a dormancy period prevents organ development during adverse climatic conditions. Whereas the phenology of leaves and flowers has received considerable attention, to date, little is known regarding the phenology of other tree organs such as wood, fine roots, fruits, and reserve compounds.

- Aims Here, we review both the role of environmental drivers in determining the phenology of tree organs and the
\end{abstract}

Handling Editor: Jean-Michel Leban

Contribution of the co-authors ND designed the paper.

ND, YV, IC, CBKR, JG, and SB wrote the paper.

ND and JG made the figures.

TR commented the paper.

Nicolas Delpierre

nicolas.delpierre@u-psud.fr

Yann Vitasse

vitasse.yann@gmail.com

Isabelle Chuine

isabelle.chuine@cefe.cnrs.fr

Joannès Guillemot

joannes.guillemot@u-psud.fr

Stéphane Bazot

stephane.bazot@u-psud.fr

This Rutishauser

matthias.rutishauser@giub.unibe.ch

Cyrille B. K. Rathgeber

cyrille.rathgeber@nancy.inra.fr models used to predict the phenology of tree organs in temperate and boreal forest trees.

- Results Temperature is a key driver of the resumption of tree activity in spring, although its specific effects vary among organs. There is no such clear dominant environmental cue involved in the cessation of tree activity in autumn and in the onset of dormancy, but temperature, photoperiod, and water stress appear as prominent factors. The phenology of a given organ is, to a certain extent, influenced by processes in distant organs.

- Conclusion Inferring past trends and predicting future trends of tree phenology in a changing climate requires specific phenological models developed for each organ to consider the phenological cycle as an ensemble in which the environmental cues that trigger each phase are also indirectly involved in the subsequent phases. Incorporating such models into terrestrial ecosystem models (TEMs) would likely improve the accuracy of their predictions. The extent to which the coordination of the phenologies of tree organs will be affected in a changing climate deserves further research.

Laboratoire Ecologie Systématique et Evolution, Université ParisSud, UMR8079, Orsay, France

2 Institute of Geography, University of Neuchatel, Neuchatel, Switzerland

3 Snow and Landscape Research, WSL Swiss Federal Institute for Forest, Neuchatel, Switzerland

4 Group Mountain Ecosystems, WSL Institute for Snow and Avalanche Research SLF, Davos, Switzerland

5 CNRS, Centre d'Ecologie Fonctionnelle et Evolutive, UMR 5175, Montpellier, France

6 Institute of Geography, University of Bern, Bern, Switzerland

7 INRA, LERFOB, UMR 1092, Champenoux, France 
Keywords Dormancy $\cdot$ Budburst $\cdot$ Autumn senescence . Cambium $\cdot$ Fine roots $\cdot$ Models

\section{Introduction}

Humans have long been interested in the seasonality and recurrences of natural events. Aside from the fundamental need to identify the most favorable periods for sowing and harvesting, which likely dates back to the beginning of agriculture (over 10,000 years ago), observations of the phenological events of nature's calendar have evolved as social rituals and have become elements of the culture of several peoples around the world (e.g., the famous cherry blossom festival celebrated in Japan for over 1200 years or autumn "leaf-peeping" in Japan and North America). The timings of a number of important natural events, such as grapevine harvesting in France and cherry blossoming in Japan, that have been recorded for centuries (in diaries, agricultural calendars, and poems, etc.) have been collated into historical chronicles and used to infer past climatic conditions (Chuine et al. 2004; Aono and Kazui 2008). In the eighteenth century, the collection of phenological data developed as a pastime for certain educated people (Sparks and Carey 1995) and as a matter of scientific interest. Réaumur (1735) reported what is likely the first quantified evaluation of the influence of temperature on the occurrence of phenophases and introduced the notion of "heat sum" which, 280 years later, remains a basic component of current phenological models. Another seminal work is from Linné (1751, cited in Dahl and Langvall 2008), who initiated a network of coincident observations of plant phenophases and the local weather in Sweden. The proper birth of phenology as a scientific discipline occurred in the nineteenth century, with both the coining of the term "phenology" by the Belgian scientist Charles Morren (in 1853; Demarée and Rutishauser 2011) and the establishment of several phenological networks throughout Europe (see Koch 2008), which unfortunately, in the majority of cases, were not perpetuated (but see Schaber and Badeck 2005). In the 1950s, large-scale phenological surveys were revived under both the initiative of national weather services in several European countries and the constitution of the International Phenological Gardens network (Menzel 2013). In combination with more recently established professional and citizen science networks, these surveys remain sources of ground-based phenological data.

A long evolutionary history has resulted in the precise timing of tree annual developmental cycles, minimizing the damage associated with abiotic stresses while maximizing tree reproductive output. In temperate and boreal trees, the main adaptation is realized as a so-called dormancy period in autumn and winter, which prevents organ development during adverse climatic conditions. The timing of phenophases in trees is known to affect their biological functions and ecological interactions at several organizational scales. There is ample evidence that year-to-year variations in leaf phenology modulate ecosystem carbon (Goulden et al. 1996; Barr et al. 2004; Delpierre et al. 2009b), water, and energy balances (Wilson and Baldocchi 2000). At the community scale, the timing of leafing is known to condition the fitness of insect herbivores that feed on trees (Tikkanen and Julkunen-Tiitto 2003), with potential consequences at upper levels of the trophic web (Visser and Holleman 2001; Visser et al. 2006; Donnelly et al. 2011). Comparatively, considerably less effort has been focused on assessing the impact of phenology on the functioning of individual plants. It is commonly observed that understory adult trees and seedlings "avoid" shading from the overstory as a result of phenological shifts (i.e., hastening of spring phenophases; Augspurger and Bartlett 2003; Vitasse 2013), which is thought to improve the understory carbon balance (Jolly et al. 2004).

The phenology of leaves has been well studied, and the timing of leaf phenology has proven to be crucial in controlling the acquisition of carbon, the loss of water, and the internal nutrient cycling in trees. In contrast, the phenology of other organs, i.e., wood, fine roots, and reproductive structures, has received less attention, even though it likely influences overall plant functioning and fitness. An example is the influence of the differential timing of wood and leaf growth in sessile oak (a ring-porous species) and European beech (a diffuse-porous species) on the amplitude of the draw-down of carbohydrate reserves observed in spring (Barbaroux and Bréda 2002). Similarly, fine-root phenology is expected to directly influence mineral acquisition (Nord and Lynch 2009), with potential impacts on individual fitness. Finally, phenology has been shown to be a key determinant of tree fitness and tree species distribution (Chuine 2010).

It is striking that the vast majority of published studies on the "phenology" of forest trees in fact refer to the seasonality of leaves. This discrepancy is likely, in part, attributed to the fact that the phenology of leaves is relatively more "apparent" and, therefore, easier to monitor than the phenologies of other organs (e.g., wood and fine roots). In addition to the growing number of observational reports on leaf phenology, a number of studies published during the previous 20 years have been dedicated to the modeling of leaf phenology (Hänninen and Kramer 2007; Chuine et al. 2013), resulting in the development of models that have been incorporated, with moderate success (see Richardson et al. 2012), into terrestrial ecosystem models (TEMs). In contrast, as a consequence of the scarcity of papers documenting the phenology of non-leafy organs in forest trees, the underlying organ-specific phenological processes are often poorly represented in models. As an example, only a small number of papers have been published to date on the modeling of wood phenology. In this context, the

\footnotetext{
${ }^{1}$ From the Greek root $\varphi \alpha \mathrm{l} v o \mu \alpha \mathrm{l}$, "to appear".
} 
phenology of non-leafy organs (i.e., reproductive structures, wood, fine roots) has often been ignored in TEMs and, when represented, defined relative to that of leaves, despite an increasing amount of evidence that suggests there are not simple links between the phenologies of tree organs. The phenologies of non-leafy organs clearly deserve proper characterization, as there is increasing evidence that the growth of tree organs does not solely depend on the fueling of carbon from the canopy but, rather, is at least transitorily an active process modulated by seasonal variations in the ability of the organ to grow (Fatichi et al. 2014; Dietze et al. 2014).

A few articles have recently reviewed the environmental determinism of and the modeling of the phenology of leaves in temperate and boreal trees (Badeck et al. 2004; Hänninen and Tanino 2011; Chuine et al. 2013; Hanes et al. 2013; Richardson et al. 2013), the phenology of flowering in temperate plants (Tooke and Battey 2010), and the phenology of non-structural carbon allocation in trees (Dietze et al. 2014). In the present review, we aim to enlarge the scope of these studies and propose to review our understanding of the phenologies of tree organs in temperate and boreal forest trees. In this paper, henceforth, we use the term "phenology" in its most functional sense, i.e., the study of the timing of detectable phase transitions between tissue states associated with major functional changes. In the first section, we synthesize the most recent knowledge on the influence of environmental cues on the phenology of temperate and boreal forest trees. We focus on leaf and reproductive structures, wood, and fine roots, also considering carbon and nitrogen reserves, which are key to the integrated functioning of trees. We conclude this section by examining links between the individual phenologies of these organs, considering an integrated view of phenology at the tree scale, because we believe that such an ensemble approach is necessary for advancing our understanding of the determinism of phenology and its response to climate change. In the second section, we review the state of development of process-based phenological models for tree organs and examine the representation of phenology in TEMs.

\section{The influence of climate on tree phenology}

A long evolutionary history has shaped the ability of temperate and boreal trees to cope with freezing winter temperatures. In autumn, leaves of deciduous trees escape winter freezing via a senescence process that leads to leaf abscission. All overwintering tree tissues, which include leaves in evergreen species, undergo a process of cold acclimation to cope with winter freezing (Yoshie and Sakai 1982). The primary and secondary meristems further enter dormancy, a resting state under which no growth or tissue maturation is observed (Mellerowicz et al. 1992; Arora et al. 2003). We begin this section by reviewing the current knowledge on the environmental controls of the dormancy/activity cycle of tree meristems (for leaves and reproductive structures, stem wood and fine roots). We then examine their impacts on carbon and nitrogen reserves, which are key to the integrated functioning of trees. We conclude by describing an integrated view at the tree scale, addressing the links between the individual phenologies of tree organs.

\subsection{Phenology of leaves and reproductive structures}

Among the overwintering tissues of temperate and boreal trees, buds are essential because they contain primordia of the future leaves or needles. The regulation and maintenance of bud dormancy is key to understanding the phenological responses of trees to climate change. The physiological processes involved in bud dormancy are complex and interact with environmental cues to optimize the timing of budburst in relation to the mean long-term probability of a late spring frost. In this section, we focus on the environmental cues that affect the phenology of the primary aerial meristems of temperate and boreal trees (budburst, flowering, fruit and cone maturation, and leaf senescence) and refer to the detailed reviews of Wareing and Saunders (1971), Arora et al. (2003), Horvath et al. (2003), and Cooke et al. (2012) for the hormonal and molecular changes involved in these phenophases.

New buds (either vegetative, reproductive, or compound) are formed from late summer to early autumn, depending on the species and the prevailing climate. Bud-set of boreal trees tends to occur earlier than in temperate trees, and within species, populations from higher latitudes or elevations exhibit earlier bud-set (Alberto et al. 2013). Once formed, buds undergo three main phases of dormancy from the summer to the following spring, namely, paradormancy, endodormancy, and ecodormancy (Fig. 1). During paradormancy (from summer to early autumn), bud cell growth is repressed by distant organs within the branch (leaves or other buds) via the influence of hormones, such as auxins (Horvath et al. 2003). During endodormancy (early autumn to mid-winter), bud cell growth is inhibited by internal factors that are still not completely understood, but that are opposed by low temperatures, hereafter called chilling temperatures. A study conducted on Betula pubescens suggests that the connections between bud meristematic cells are progressively re-established via plasmodesmal channels after a certain time of exposure to chilling temperatures (Rinne et al. 2001), possibly explaining the transition between the endodormancy and ecodormancy phases. The end of bud endodormancy classically corresponds to the socalled dormancy break. During ecodormancy (mid-winter to mid-spring), bud cell growth is inhibited by unfavorable external climatic conditions. The categorization of bud dormancy into three phases is convenient from a conceptual viewpoint and has thus been incorporated into the building of processbased models (see section 3.1 "Modeling the phenology of 


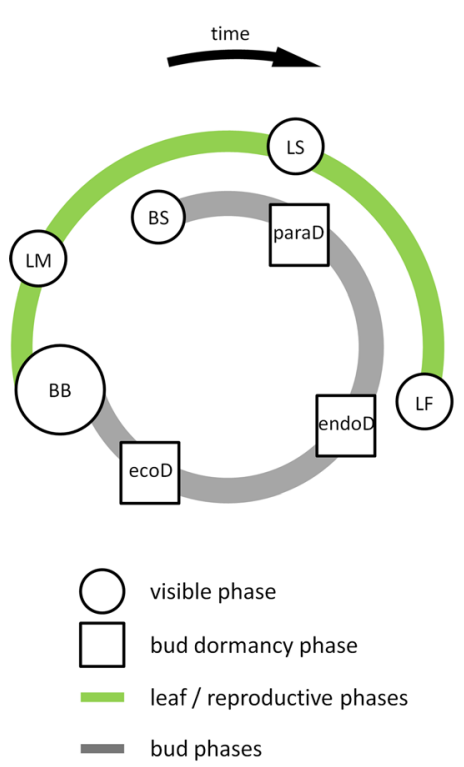

Fig. 1 Influence of environmental controls on the timing of leaf and reproductive structures phenophases in temperate and boreal forest trees. The cycles illustrate the seasonal progress of the ontogenetic development of the primary aerial meristems. The phenological events are listed in the table with their corresponding drivers. Parentheses indicate facultative roles. No cues are identified for budburst/flowering and leaf fall/fruit shedding, which are the outcomes of the preceding

leaves and the timing of flowering"). Nevertheless, this definition, originally proposed by Lang et al. (1987), is currently under scrutiny because it appears that these three bud dormancy phases are not strictly separated in time, and interactions among these phases have been reported (Cooke et al. 2012).

Overall, in temperate and boreal forest trees, bud development is mainly under the control of temperature and photoperiod cues. Whereas the influence of temperature has been well documented in recent decades, especially with respect to the timing of budburst (e.g., Linkosalo et al. 2006; Menzel et al. 2006; Linkosalo et al. 2009), the understanding of the influence of photoperiod still generates intense debate within the scientific community (e.g., Körner and Basler 2010 and the reply in Chuine et al. 2010; Laube et al. 2014). Temperature has contrasting effects on bud development depending on the dormancy state (endodormancy versus ecodormancy, Fig. 1). Indeed, it has been assumed since the beginning of the twentieth century that, for the majority of temperate and boreal tree species, a certain duration of chilling temperatures ranging between 0 and $5{ }^{\circ} \mathrm{C}$ is responsible for the release from endodormancy (Coville 1920; Sarvas 1974; Hänninen 1990; Caffarra et al. 2011b). However, the range of chilling temperatures required for an efficient release from endodormancy has not yet been clearly identified (Dantec et al. 2014). Recent advances suggest that this range of chilling temperature is likely to be species-specific (Laube et al. 2014) and may cover a broader spectrum than commonly assumed (Harrington et al.

\begin{tabular}{|c|c|c|}
\hline Code & $\begin{array}{l}\text { Phenological } \\
\text { phase or stage }\end{array}$ & Environmental cue \\
\hline BS & Bud-set & $\begin{array}{c}\text { daylength } \\
\text { temperatures }\end{array}$ \\
\hline paraD & Paradormancy & distal hormonal contro \\
\hline endoD & $\begin{array}{l}\text { Endodormancy } \\
\text { induction } \\
\text { Endodormancy } \\
\text { break }\end{array}$ & $\begin{array}{l}\text { low temperature, } \\
\text { short daylength } \\
\text { low temperature }\end{array}$ \\
\hline $\begin{array}{l}\text { ecoD } \\
\text { BB }\end{array}$ & $\begin{array}{l}\text { Ecodormancy } \\
\text { Budburst } \\
\text { Flower/cone } \\
\text { emergence }\end{array}$ & $\begin{array}{l}\text { warm temperature } \\
\text { long daylength }\end{array}$ \\
\hline LM & Leaf maturation & warm temperature \\
\hline LS & Leaf senescence & $\begin{array}{l}\text { low temperature, } \\
\text { short daylength } \\
\text { (water stress) }\end{array}$ \\
\hline & $\begin{array}{l}\text { Fruit / cone growth } \\
\text { and maturation }\end{array}$ & warm $T$ \\
\hline LF & $\begin{array}{l}\text { Leaf fall } \\
\text { Fruit / seed } \\
\text { shedding }\end{array}$ & \\
\hline
\end{tabular}

phases. The figure strictly applies to deciduous angiosperms, the leaves and fruits of which mature and are shed within 1 year. In conifers, leaves (needles) live 2 to 10 (or more) years (depending on the species and climate conditions; see Jalkanen et al. 1995), and a 2-year (up to 3year) maturation period is the rule for cones before seed shedding (Pallardy 2008)

2010). Once endodormancy is released, warm temperatures have a clear positive effect on bud development during ecodormancy, with a warmer spring leading to an earlier budburst (Sarvas 1972; Sarvas 1974; Campbell and Sugano 1975; Lang et al. 1987; Caffarra et al. 2011b). The influence of warm spring temperatures is particularly obvious in mountainous areas, where tree populations flush gradually later toward higher elevations (Vitasse et al. 2009), with only a small fraction of the variability explained by the genetic differentiation among populations (Vitasse et al. 2013). Finally, several studies have suggested that the influence of a warm temperature in early spring depends on the state of bud endodormancy and, in certain species (such as Fagus sylvatica or Picea abies), on the current photoperiod (Heide 1993; Myking and Heide 1995; Caffarra et al. 2011b; Vitasse and Basler 2013; Basler and Körner 2014; Laube et al. 2014). However, the effect of the photoperiod on the resumption of bud cell division and growth during ecodormancy varies widely among species and has been reported to clearly affect the timing of budburst in only one third of the temperate and boreal tree species for which this factor has been explicitly tested in experiments (18 out of 55 tree species, mainly temperate trees; Way and Montgomery 2014). Both the chilling requirement and photoperiod controls are regarded to prevent overly precocious leaf, needle, or flower development in relation to the timing of late frost events, and these two controls can be considered the most prominent adaptations to preventing injury from frost. 
The seasonal development of reproductive structures has received considerably less attention in forest trees than in crop trees (Sedgley and Griffin 1989; Srivastava 2002). The ontogenetic sequence from the apparition of flowers (in angiosperms) or strobili (in gymnosperms) to the time of fruit ripening or seed maturation involves a number of stages (i.e., pollination, fertilization, the growth and differentiation of the embryo; Pallardy 2008) that we group here under the term of fruit (or cone) maturation. The seasonality of fruit (cone) maturation (in terms of size and mass) is relatively well documented (see, e.g., Sharp and Spargue 1967, Fujii 1993 in temperate deciduous oaks; Linder and Troeng 1981, Koppel et al. 1987 in boreal conifers), but there is scarce information regarding the environmental dependence of these processes. Temperature has been identified as a cue for both cone maturation (Mutke et al. 2003) and seed maturation (Meunier et al. 2007) in conifers.

Bud-set (i.e., the formation of a mature, dormant bud) must be initiated in summer before the occurrence of the first frost, as a prerequisite to the initiation of cold acclimation. The timing of bud-set closely follows the cessation of primary shoot growth (Gyllenstrand et al. 2007; Rohde et al. 2011). It is often assumed that the autumnal cessation of primary meristem activity and bud-set are fully controlled by the photoperiod (detected by the phytochrome receptor) in the majority of temperate tree species (Tanino et al. 2010; Way 2011). However, recent experimental studies have demonstrated that temperature additionally modulates the timing of bud-set and the cessation of primary growth in a number of temperate and boreal tree species (e.g., Salminen and Jalkanen 2007), with both temperature and photoperiod acting in an interactive, non-monotonous manner (Rohde et al. 2011; Heide 2011).

The timing of leaf senescence has received considerably less attention than leaf unfolding in forest trees, likely because it affects tree productivity to a relatively small extent because the meteorological and light conditions in autumn are substantially less optimal for photosynthesis than the conditions in spring (Vitasse et al. 2009). Leaf senescence is also relatively more difficult to monitor because, in contrast to budburst (which occurs in a few days and involves morphological changes that are easy to detect), leaf senescence is a slow, continuous ensemble of processes, visually progressing from the leaf coloration induced by the degradation of chlorophylls to, ultimately, leaf fall. The recent development of satellitebased and ground-based imagery (Hmimina et al. 2013; Keenan et al. 2014) is expected to increase the level of research effort on the leaf senescence phase. Temperature and photoperiod are regularly mentioned as the most influential environmental cues in triggering leaf senescence, but their respective contributions have not been fully elucidated (see Estrella and Menzel 2006). Several stresses, such as drought (Hwang et al. 2014; Estiarte and Peñuelas 2014), water logging, and mineral deficiencies
(Smart 1994), can also hasten leaf senescence, primary growth cessation, and bud-set.

Finally, it is important to consider that the different phenophases considered here (e.g., bud-set, budburst, leaf maturation, and leaf senescence) are all interconnected. A change in the timing of one phase can potentially affect the timing of subsequent phases (Hänninen and Kramer 2007; Fu et al. 2014). Hence, the environmental cues driving the timing of each phase are also indirectly involved in the timing of subsequent phases, as described in Fig. 1.

\subsection{The phenology of wood formation}

The formation of wood (secondary xylem), known as xylogenesis, results from a sequence of cellular processes. (1) The division of a cambial initial produces a xylem mother cell, which in turn produces several undifferentiated xylem cells. The differentiation of these future xylem cells then operates through (2) cell expansion, (3) secondary cell-wall deposition, (4) cell-wall lignification, and (5), in the case of conductive elements, programmed death (Wilson et al. 1966; Plomion et al. 2001). This sequence is common to both angiosperms and gymnosperms but involves different cell types and molecular components, resulting in different tree-ring structures (Plomion et al. 2001). The key phenological events in the process of wood formation are the beginning and end of cambial cell division or xylem cell expansion (both are used as proxies for the onset and cessation of cambial activity), the beginning of secondary cell-wall deposition, and the end of cell-wall lignification (used as a proxy for the cessation of wood formation) (see Rathgeber et al. (2011a) for detailed definitions and assessment of these events) (Fig. 2). Recently, it has been demonstrated that this sequence of events is structurally fixed (Lupi et al. 2010; Rossi et al. 2012) and that the delays between the beginning and the end of successive wood phenophases are highly conserved among temperate and boreal trees (Rossi et al. 2013). Considering that the xylem cells produced by cambial division must undergo long differentiation processes, an earlier onset or a higher rate of cambial activity, presumably associated with a higher number of cells produced along the growing season, would result in a later cessation of wood formation (Rathgeber et al. 2011b; Rossi et al. 2012; Kalliokoski et al. 2013).

Despite these strong structural constraints, environmental factors are also known to have significant influences on the timing of wood formation (Denne and Dodd 1981). Both external and internal factors control xylogenesis (Wilson 1984; Aloni 2013) and are likely involved in the regulation of its timing (Lachaud et al. 1999). Among these factors, temperature is expected to be a major cue for the phenology of xylogenesis, considering its influence on cell structure (Begum et al. 2012) and on basic processes, such as the modulation of the division rate of cambium initials (Begum et al. 
Fig. 2 Influence of environmental controls on the timing of wood phenophases in temperate and boreal forest trees. The cycles illustrate the seasonal progression of the ontogenetic development of stem secondary meristems. The corresponding phenological and physiological events are listed in the table with their corresponding environmental drivers. Question marks indicate uncertain roles or missing evidence. Parentheses indicate hypothetical states. The $\mathrm{CDO}, \mathrm{XEO}$, and $\mathrm{CWO}$ phases are the outcomes of the ecodormancy break

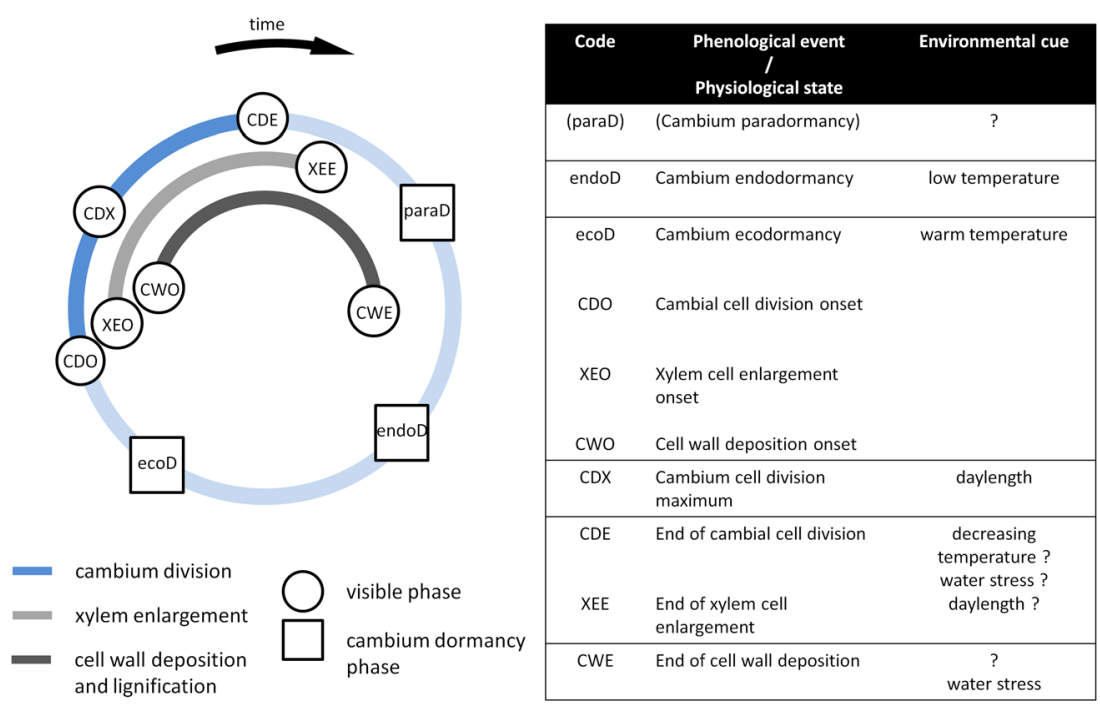

2013) and the regulation of gene expression related to active auxin transport (Schrader et al. 2003).

To date, the majority of research efforts on the phenology of wood formation have been conducted in conifers, mainly in high-altitude or northern locations. There are comparatively fewer data on deciduous angiosperms in the recent literature, and among them, the majority relate to diffuse-porous (as opposed to ring-porous) species. The results of these studies indicate a primary role of temperature as an environmental cue for xylogenesis (Fig. 2). In natural stands, the onset of cambial activity occurs within a relatively narrow range of daily minimum air temperature $\left(+2\right.$ to $+7^{\circ} \mathrm{C}$ in $80 \%$ of the data; Rossi et al. 2008), resulting in altitudinal gradients of cambium resumption (Moser et al. 2010; Oladi et al. 2010; Prislan et al. 2013). Moreover, the resumption of cambial activity can be triggered during late winter by an artificial heating of tree stems (Oribe et al. 2003; Begum et al. 2007, 2010). Interestingly, this artificial resumption of cambial activity can only be triggered during the ecodormancy phase of cambium tissue (referred to as the "quiescent phase" in Oribe and Kubo 1997; Begum et al. 2013) after the chilling requirement has been fulfilled during endodormancy (referred to as the "rest phase" in Little and Bonga 1974; Begum et al. 2013). However, the influence of temperature on cambium activity remains equivocal. Indeed, the cessation of the division of cambial initials in late summer or autumn occurs at considerably milder temperatures than those for spring resumption (between $+5^{\circ} \mathrm{C}$ and $+13^{\circ} \mathrm{C}$ for gymnosperms, Rossi et al. 2008), but cessation can be hastened by artificial cooling (Gričar et al. 2007). This equivocal role of temperature results in the absence of clear altitudinal gradients in the timing of the cessation of cambial activity (Moser et al. 2010; Oladi et al. 2010; Prislan et al. 2013). This body of results clearly demonstrates that cambium division does not simply respond to the occurrence of certain temperature thresholds but that other environmental cues are involved in the timing of cambium activity. Soil drought, for instance, has been suggested to hasten the cessation of cambial activity (Dünisch and Bauch 1994; Gričar and Čufar 2008), though this result is not systematically observed (Gruber et al. 2010). Day length, which likely modulates the rate of cambial division (Rossi et al. 2006; Cuny et al. 2012), may also act as a cue for the cessation of cambial activity, but this hypothesis remains to be tested. Finally, the ending of xylem differentiation, which marks the end of annual wood formation, occurs at similar temperatures to the prevailing temperatures during the onset of cambium cell division (Rossi et al. 2008). The ending of xylem differentiation generally occurs earlier at higher altitudes (Moser et al. 2010) and can be hastened by drought (Gruber et al. 2010).

\subsection{The phenology of fine roots}

Adult tree roots are organized as structured systems of several branching orders. There is clearly not a single class of "fine roots" that can be easily identified on the basis of morphological criteria (e.g., diameter, Pregitzer 2002) but, rather, a continuum of sizes, functions (Guo et al. 2008), and lifespans (King et al. 2002) across branching orders. Accordingly, the study of the elementary phases of root phenology (i.e., the onset of production and shedding of a root segment) would benefit from the consideration of multiple branching orders individually. Presumably, and thus in this review, substantial effort should be focused on describing the phenology of the finest, "ephemeral" roots (Eissenstat et al. 2013) because these roots constitute the most dynamic part of the root system. These ephemeral roots are typically less than $1 \mathrm{~mm}$ in diameter, non-woody, and mycorrhizal and play the main role in the absorption of water and nutrients (Guo et al. 2008). However, the reality of field observations is that the 
phenological patterns of production and mortality are studied for ensembles of root branching orders that usually consider fine roots as the roots below a given diameter threshold of 1 or $2 \mathrm{~mm}$.

We deal here with the primary growth of fine roots. The extent to which the primary growth of fine roots in trees is indeterminate (or not) remains unknown (Shishkova et al. 2008). However, minirhizotron studies have demonstrated clearly that growth and mortality may occur simultaneously in the root system. Still, in fine roots, growth and mortality are generally out of phase, creating a distinct pattern for the overall phenologies of root systems. Characteristic features for temperate and boreal trees are a burst of fine root growth in spring/summer and significant mortality in late summer/ autumn (Pregitzer et al. 2000; Joslin et al. 2001; see also McCormack et al. 2014) (Fig. 3), resulting in strikingly similar overall patterns of fine root production and mortality among deciduous and evergreen tree species growing under the same climate (Quan et al. 2010).

Overall, soil temperature has been shown to regulate fine root elongation in forest trees. Fine root elongation does not occur below a +2 to $+4{ }^{\circ} \mathrm{C}$ threshold (Alvarez-Uria and Körner 2007; Schenker et al. 2014), with species-specific optima between +20 and $+30{ }^{\circ} \mathrm{C}$ (Lyr and Hoffmann 1967; Dougherty et al. 1994). This temperature cue is likely dominant in the pattern of root formation, driving (1) spring or early-summer bursts and (2) autumn strong decreases in or cessation of fine root production, irrespective of the functional group or leaf phenology (Teskey and Hinckley 1981; Kuhns et al. 1985; Hendrick and Pregitzer 1992; Burke and Raynal 1994; Puhe 2003; Konôpka et al. 2005; McCormack et al. 2014). A few studies have suggested that fine root growth can continue at a minimal rate during winter in evergreen trees (Dougherty et al. 1994; Puhe 2003), a feature that is clearly not systematic (Noguchi et al. 2005; Quan et al. 2010; McCormack et al. 2014). Fine root growth may also be reduced (Joslin et al. 2001) or interrupted under drought conditions (Teskey and Hinckley 1981; Kuhns et al. 1985; Konôpka et al. 2005), as defined by a species-specific soil water potential threshold (see Joslin et al. 2001).

We still know very little regarding the environmental controls on the mortality of fine roots (Pregitzer 2002), but studies of fine root lifespans suggest that both elevated temperatures and soil moisture deficits promote root mortality (Pregitzer et al. 2000; Eissenstat et al. 2013). In addition to interspecific differences (Leuschner et al. 2001) and methodological aspects (Gaul et al. 2008), non-linearity and differential sensitivities among the responses of fine root growth and mortality to soil water deficits likely contribute to the variation among the responses of root biomass to soil drought observed in field studies, which have reported both increases (Joslin and Wolfe 1998; Leuschner et al. 2001) and decreases (Konôpka et al. 2005) in live root biomass. Interestingly, overwinter mortality is minimal, resulting in the maintenance of a substantial fine root stock during winter (Hendrick and Pregitzer 1992; Konôpka et al. 2005).

The secondary growth of higher-order roots has seldom been studied (Chaffey 2013), but is subjected to the same cascade of phenological events as stems or branch wood. The timing, however, differs and generally follows an extended calendar, with an earlier timing of onset and later cessation of the differentiation period compared to stem wood (Thibeault-Martel et al. 2008).

\subsection{The phenology of carbon and nitrogen reserves}

Carbon $(\mathrm{C})$ and nitrogen $(\mathrm{N})$ reserves are key actors in the seasonal variability of temperate and boreal tree functioning. Carbon reserves are primarily formed from non-structural compounds, including starch and soluble sugars, as well as lipids in a number of species (Hoch 2015). Nitrogen reserves are composed of non-structural compounds, including the socalled vegetative storage proteins, amino acids (Staswick 1994), and a range of metabolically active proteins, such as Rubisco (Millard et al. 2007). Both the $\mathrm{C}$ and $\mathrm{N}$ reserve stores are distributed throughout the tree. A gradient from low concentrations of reserve compounds in the stem to higher

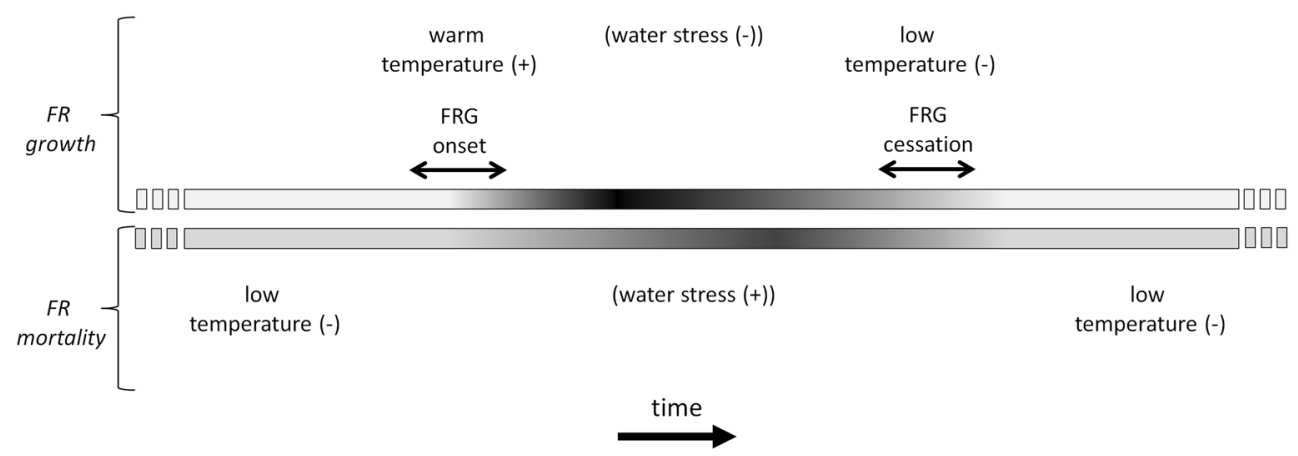

Fig. 3 Influence of environmental controls on the timing of fine root phenology in temperate and boreal forest trees. Continuous processes of fine root (FR) growth and mortality are depicted, with various intensities during the calendar year indicated by gray shading. The influences of the main environmental controls are denoted as $(+)=$ promotion or $(-)=$ reduction. Parentheses indicate facultative controls 
concentrations in distal organs (branches and leaves, coarse roots; Bazot et al. 2013) is partially counterbalanced by the size of compartments; hence, the stem remains a quantitatively important store of C (Barbaroux et al. 2003) and $\mathrm{N}$ reserves (Valenzuela Nuñez et al. 2010). In the following, we focus on the seasonal variations in the stores of $\mathrm{C}$ and $\mathrm{N}$ reserves, acknowledging the existence of diurnal variations in transient reserves forms of $\mathrm{C}$ (such as starch) in leaves (e.g., Zeeman et al. 2007) and $\mathrm{N}$ (mainly amino-acids) in roots (Geßler et al. 2002). Traditionally, the storage of $\mathrm{C}$ and $\mathrm{N}$ reserves has been viewed as a passive process according to which $\mathrm{C}$ and $\mathrm{N}$ are allocated to reserve stores after other demands (e.g., the growth of organs or maintenance respiration) have been met. Consequently, the phenologies of $\mathrm{C}$ and $\mathrm{N}$ reserves have primarily been described relative to that of tree organs. The timing of resource acquisition obviously varies with tree functional type, imposing notable differences on the seasonal dynamics of reserves.

Budburst and the growth of new organs (leaves, wood, fine roots) induce a massive, short-distance mobilization of reserves in deciduous trees (Bazot et al. 2013). This mobilization typically results in a decrease in concentrations of $\mathrm{C}$ reserves in the majority of tree organs (Barbaroux et al. 2003). New leaves and photosynthetic twigs can act as a $\mathrm{C}$ source for a few days after budburst, which allows for a rapid increase in C reserves (Damesin and Lelarge 2003), culminating at leaf senescence (Barbaroux and Bréda 2002). The concentration of $\mathrm{C}$ reserves typically decreases during winter in deciduous trees as a result of fueling maintenance processes in perennial organs (Barbaroux and Bréda 2002). The seasonal pattern of $\mathrm{N}$ reserves is less continuous than that of $\mathrm{C}$ reserves in deciduous trees. After the spring mobilization of $\mathrm{N}$ reserves (Millard and Grelet 2010; El Zein et al. 2011; Bazot et al. 2013), $N$ reserves remain at low levels throughout the leafy season (Bazot et al. 2013), likely reflecting the balance between $\mathrm{N}$ requirements (for growth and maintenance) and supplies from the current root absorption. $\mathrm{N}$ storage is limited to autumn because it is strongly dependent on leaf senescence processes. Winter variations in $\mathrm{N}$ reserves have been studied considerably less frequently, but the level of variation appears to be reduced compared to that in C reserves (Gomez and Faurobert 2002; Valenzuela Nuñez et al. 2011; El Zein et al. 2011; Gilson et al. 2014).

In evergreen species, the mobilization of $\mathrm{C}$ reserves for the development of new tissues is not as strong as for deciduous trees. Conifers can perform photosynthesis during the winter when the air temperature is above -2 to $-3^{\circ} \mathrm{C}$ (Bergh et al. 1998); therefore, sprouting buds are supplied $\mathrm{C}$ from the previous needle cohort (Ursino et al. 1968). The seasonal dynamics of $\mathrm{C}$ reserves indicate that the starch concentration peaks prior to budburst (Fischer and Höll 1991; Fischer and Höll 1992; Hoch et al. 2003), with only slight variations in C storage throughout the growing season, regardless of the considered form (including lipids) (Hoch et al. 2003). In contrast to deciduous trees, carbohydrate stores remain relatively constant in evergreen species throughout winter (Fischer and Höll 1991, 1992), whereas lipids may accumulate (Sudachkova et al. 2004). A remobilization of $\mathrm{N}$ from older shoots (Salifu and Timmer 2003) or the needles from the previous year (Millard and Proe 1992) provides the N necessary for the growth of newly formed tissues. Fluctuations of $\mathrm{N}$ reserves in evergreen species have not been well studied for the rest of the year but appear to be less variable than those of C reserves (Millard and Grelet 2010).

The extent to which the formation of $\mathrm{C}$ reserves is an active process is a current matter of discussion (see reviews by Hoch in press; Palacio et al. 2014; Dietze et al. 2014). There is evidence that even under severe stress conditions, $\mathrm{C}$ reserves are never fully depleted (Gruber et al. 2012; Hartmann et al. 2013; Klein et al. 2014) and that reserve storage may, in certain cases, be favored at the expense of growth (Wiley et al. 2013; Saffell et al. 2014). Recent studies have demonstrated that, within a given growing season, the formation of $\mathrm{C}$ reserves occurs earlier in mature trees compared to young trees in experiments conducted under the same pedoclimatic conditions and leaf phenology (Gilson et al. 2014). The extent to which this pattern results from a differential regulation of active $\mathrm{C}$ storage in mature trees versus young trees or is simply the result of differences in the seasonal $\mathrm{C}$ balance has not yet been determined (e.g., through modeling). Identifying the nature and influence of the internal and environmental factors that drive reserve storage processes is an open field for future research. Seasonal reserve storage is likely to be highly regulated (biochemically and genetically), but the mechanisms involved remain to be elucidated.

\subsection{Integrated phenology at the tree scale}

In temperate and boreal trees, the synchronization of the activities of organs is vital and shapes the seasonal variability in the assimilation and use of resources (e.g., for growth, reproduction, and storage) at the tree scale. The phenology of each organ is controlled by an ensemble of environmental and internal drivers that modulate the progress of an invariant ontogenetic pattern of development from the first meristem cell division until organ maturity. The current state of knowledge regarding the influence of environmental variables on the phenologies of tree organs was reviewed in the previous sections. The internal factors involved in the phenology of the organs are numerous and have been well studied, though large gaps in knowledge remain. Phytohormones and sugars are among the prominent internal factors that regulate the phenology of organs (e.g., Horvath et al. 2003). The phytohormones produced in a given organ can regulate the phenology of distant organs. For instance, during the paradormancy of buds (from bud-set to early autumn, Fig. 1), bud development is likely inhibited 
by the auxins produced in neighboring leaves (Horvath et al. 2003). Similarly, auxins produced in expanding buds influence the rate of stem cambial divisions (Little and Bonga 1974; Lachaud et al. 1999). These examples indicate that the phenology of a given organ may, to a certain extent, be influenced by processes in distant organs and raise the question of the autonomy of an organ's phenology.

Clear evidence of distinct sequences in the phenologies of wood and leaves has been reported in deciduous angiosperms (Lachaud and Bonnemain 1981; Suzuki et al. 1996). These references document distinct patterns among tree functional types with regard to the relative onsets of cambium division and leaf appearance. In the majority of diffuse-porous trees, the onset of cambium division occurs simultaneously with or a few days after budburst (Suzuki et al. 1996; Čufar et al. 2008; Michelot et al. 2012; Prislan et al. 2013), though delays of several weeks have been observed in a number of species (e.g., as long as 8 weeks in Carpinus betulus; Delaporte (2010)). Ring-porous trees are relatively more vulnerable to freezing-induced embolism than diffuse-porous species (Cochard and Tyree 1990). In the former, a functional xylem that allows for a sufficient water supply to the expanding leaves is rebuilt in the spring. Hence, xylogenesis begins prior to budburst in ring-porous trees. In certain ring-porous species (deciduous oaks), the onset of cambial division is the first step of spring resumption (Gričar 2010; González-González et al. 2013), whereas in others (e.g., Fraxinus excelsior), overwintering vessels start to enlarge before budburst (SassKlaassen et al. 2011) and cambial division is resumed after budburst (Frankenstein et al. 2005). In conifers, the resumption of cambium activity generally occurs before budburst (Rossi et al. 2009; Gruber et al. 2010; Cuny et al. 2012; Michelot et al. 2012; Huang et al. 2014).

Differences in the delays between the spring phenophases of wood and leaves are also observed from year to year (Takahashi et al. 2013) and among individuals within species (N. Delpierre, unpublished results). From this ensemble of results, it is difficult to infer the influence of auxin produced in swelling or elongating buds on the timing of the onset of cambium division. The presence of auxins in overwintering tissues may decouple the onset of cambium division from the timing of bud elongation, as observed from stem heating experiments (Oribe et al. 2003; Begum et al. 2010). However, it is likely that the auxins produced in elongating buds are necessary for sustaining a high division rate in the newly activated cambium (Dufour and Morin 2010). Temperature is a major cue for all of these processes because it controls both the break from the period of ecodormancy in buds (hence, the production of auxins) and the sensitivity of cambium to auxins (see, e.g., Lachaud et al. 1999; Fonti et al. 2007; Begum et al. 2013)

The particular example of the timing of leaf and wood phenology in spring demonstrates that the influence of distance-signaling varies among species and, most importantly, is itself modulated by environmental conditions.

Further research is clearly required to evaluate the relative influence of environmental and internal controls in determining the phenologies of individual organs. Future investigations should, for instance, clarify the respective roles of environmental and internal controls on the timing of fine root elongation, which is typically observed to start before budburst (Lyr and Hoffmann 1967; Teskey and Hinckley 1981; Kuhns et al. 1985; Burke and Raynal 1994) in deciduous species and may lag several months (1 to 3 ) ahead of budburst in conifers (Puhe 2003; Konôpka et al. 2005). Further research is also required to clarify the putative role of distance-signaling molecules originating from roots in affecting the timing of budburst (Greer et al. 2005; De Barba et al. 2015) because recent results indicate that budburst can occur simultaneously in both a donor tree and its twig cuttings that have already been separated from the root system (Vitasse and Basler 2014).

\section{Modeling the phenology of temperate and boreal forest trees}

The seasonality of physiological processes is an essential component of terrestrial ecosystem models (TEMs; Kramer 1995) and of process-based species distribution models (Chuine and Beaubien 2001). This factor is key for an accurate representation of the interannual variability of the carbon balance (Delpierre et al. 2012), the tree resistance to abiotic stresses, and the tree reproductive success. However, the seasonality of physiological processes is still poorly represented in TEMs, in which phenological schemes are confined to the simulation of leaf onset and leaf loss in the simplest manner (Table 1; see, also, Richardson et al. 2012), and is still rarely used in species distribution models. Phenological models have primarily been developed for simulating the phenology of leaves and flowers, whereas the modeling of the phenologies of other organs (e.g., wood, fine roots, fruits/cones) is still in its infancy. To date, there has been no attempt to incorporate precise descriptions of the phenologies of the various organs into a single scheme. In the following section, we first review the literature on the modeling of leaves, flowers, and wood phenology for which particular organ-scale models have been published. We then identify the developments that are required for improving those organ-scale models. We close this section by reviewing the representation of the phenology of tree organs in TEMs.

\subsection{Modeling the phenology of leaves and the timing of flowering}

The modeling of leaf and flower phenology has received considerable attention over the last 60 years (Weinberger 1950) 


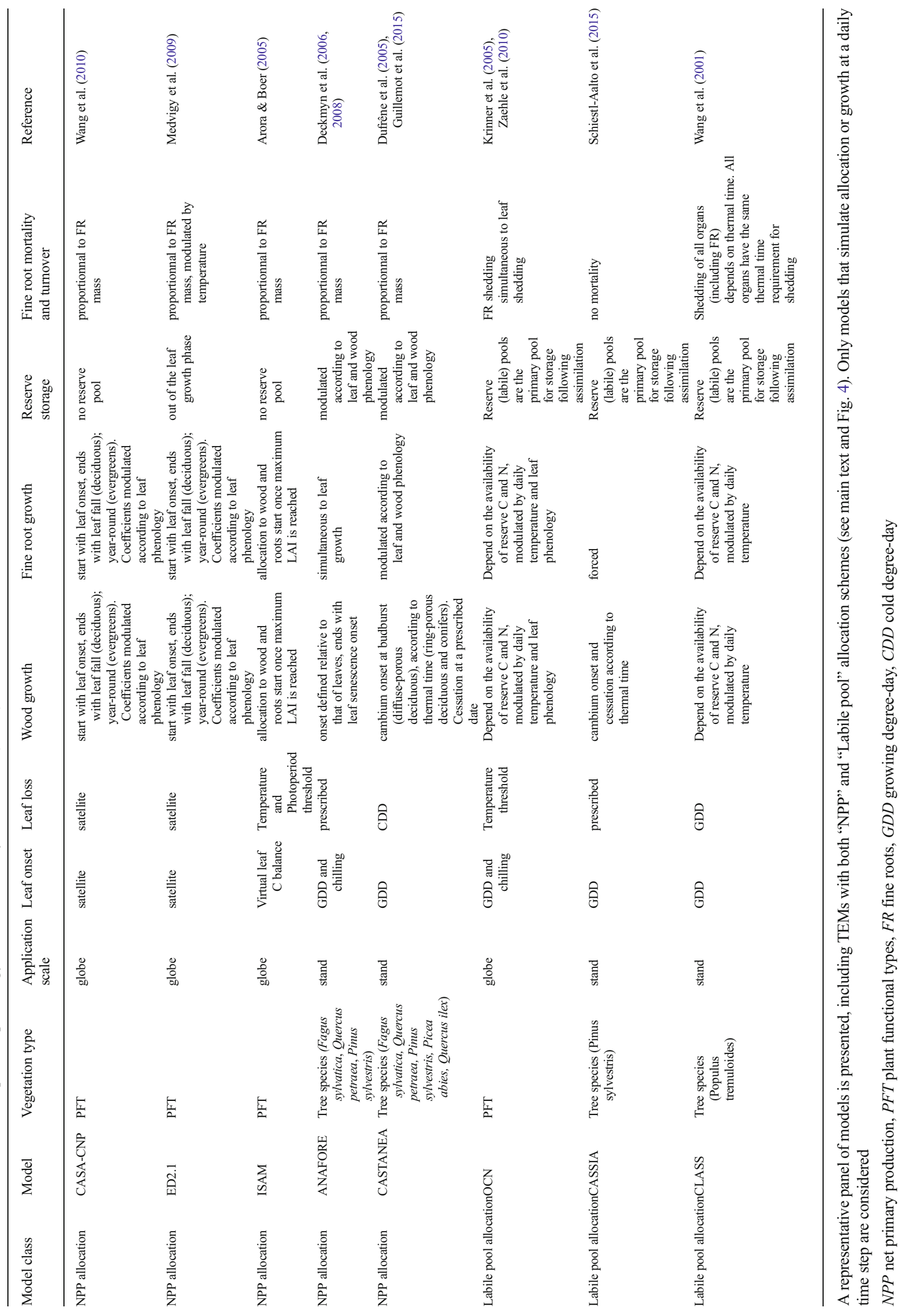


and was developed primarily in the agronomic community until the 1980s (Chuine et al. 2013). Several approaches to representing the occurrences of leaf and flower phenophases have been considered. These approaches can generally be assigned to one of the three model classes defined by Levins (1966), namely, theoretical, statistical, and process-based models. Theoretical models are based on the cost/benefit tradeoff of producing leaves to optimize resource acquisition (Kikuzawa 1991, 1995) and are used for testing hypotheses on the evolution of leaf lifespan strategies in trees rather than for predicting annual variations in plant phenology (e.g., Kikuzawa 1996). Statistical models relate the timing of phenological events to climatic factors and have been used for diagnostic purposes (the identification of climate modulators of phenology; Archetti et al. 2013) and for the spatial extrapolation of phenology (Rötzer and Chmielewski 2001; Lebourgeois et al. 2010). Process-based models formally describe the known or hypothetical cause-effect relationships between physiological processes and the environmental driving factors that were previously discussed (see section 2.1 "Phenology of leaves and reproductive structures"). In contrast to theoretical and statistical models, the parameters of process-based models have physical dimensions that can, in principle, be measured directly instead of being inferred statistically by maximum-likelihood or least-square methods applied to phenological series (Chuine et al. 2013).

Most of the differences among the process-based phenological models designed for simulating the timing of leafing or flowering relate to (1) the number of developmental phases considered from dormancy induction to leaf unfolding or flowering and (2) the response functions to temperature or photoperiod (or any other environmental driver) that are considered for each phase. In practice, there is no structural distinction among models designed for simulating the timing of leaf out (for vegetative buds) or flowering (for reproductive or mixed buds) because the processes of meristem development are essentially the same in vegetative and reproductive buds and are driven by the same environmental cues (Fig. 1) (though not necessarily at the same rate). For example, a model simulating the development of a bud can either describe (1) the single phase of ecodormancy, under the assumption that the endodormancy break date does not significantly impact the budburst date, or (2) both the progressions of the endodormancy and ecodormancy phases, which can be refined with (3) the additional description of endodormancy induction. In such process-based models, the date of occurrence of a given developmental phase $n$ (e.g., endodormancy, ecodormancy, budburst) occurs on date $t_{n}$ according to the following:

$S_{n, t_{n}}=\sum_{t=t_{n-1}}^{t=t_{n}} R_{n, t}(Z)=S_{n}{ }^{*}$ where $S_{n, t_{n}}$ is the state of development of phase $n$ on day $t_{n} ; t_{n}$ is the date of the end of phase $n$ and $t_{n-1}$ the date of the end of phase $n-1 ; R_{n, t}$ is the rate of development during phase $n$ on day $t$, which is a function of one or a set of daily or hourly environmental variables $Z$ (e.g., temperature, photoperiod, water potential, see Fig. 1); and $S_{n}{ }^{*}$ is the critical state for the completion of phase $n$. Phases can either occur sequentially, the beginning of phase $n$ at the end of phase $n-1$, or can overlap (in which case Eq. 1 is not applicable). The phenological models and rate of development functions published for the spring and summer phenophases of leaves, flowers, and fruits have been reviewed by Chuine et al. (2013). ${ }^{2}$ Considerable advances in the modeling of leaf unfolding and flowering have been realized during the previous 20 years, but these advances have not yet been incorporated into TEMs, which, in general, simulate the date of leaf onset by simply considering the degree-day accumulation during ecodormancy or with even simpler schemes (e.g., a temperature threshold) (Table 1).

The modeling of leaf senescence has clearly received less attention than that of spring phenophases. The design of leaf senescence models is accordingly more variable; however, temperature and/or photoperiod thresholds (White et al. 1997) or running means (Jolly et al. 2005) are regularly employed as triggers of leaf senescence in models (Table 1). Models of the progression of leaf senescence that are similar to Eq. 1 in their general formulation have been proposed. These models rely on the use of low temperatures and photoperiods as main environmental cues and generally outperform threshold-type models (Delpierre et al. 2009a; Yang et al. 2012; Archetti et al. 2013) but remain less accurate than budburst models, partially because the uncertainties associated with observed leaf senescence dates are considerably greater than the uncertainties regarding flowering and leaf unfolding dates.

The modeling of fruit maturation or cone development has received even less attention in forest tree species, and most studies (but see Chuine and Beaubien 2001) consider crops and fruit trees (e.g., Yin et al. 1995; Garcia de Cortazar-Atauri et al. 2009, but see Mutke et al. 2003). Fruit maturation models represent the action of temperature from the flowering date, first on fruit cell multiplication and growth and, second, on the rate of carbohydrate accumulation in the fruit. Thus, these models are based on two different response functions to temperature and consider the cumulative effects of these functions over time, similar to phenological models of leaf unfolding. Regarding forest trees, several open questions remain that can refine these models, such as the seasonal progression of the leaf-carbon dependence of fruits and cones for carbohydrate accumulation (Linder and Troeng 1981; Koppel

\footnotetext{
$\overline{{ }^{2} \text { Freeware (PMP }}$, Phenology Modeling Platform) for designing and parameterizing phenological models is available at http://www.cefe.cnrs.fr/ $\mathrm{fr} /$ recherche/ef/dream/phenology-modelling-platform.
} 
et al. 1987; Hoch 2005) and the dynamics of chemical maturation. Data on these critical processes are lacking, as are data on fruit and cone maturation dates. More generally, we lack data regarding the carbon cost of flowering and the success of fruit maturation, which are required for developing sound models of fruit production. Such models are critical for predicting both tree carbon balance and reproductive success.

\subsection{Modeling the phenology of wood growth}

Few studies presenting models of wood phenology have been published to date. Statistical models of cambium activity indicate that wood phenophases most likely occur in narrow temperature ranges (Rossi et al. 2008; Rossi et al. 2011). Unfortunately, these models do not shed light on the underlying processes that drive cambial phenology and, thus, cannot be used in a prognostic way in deterministic models of tree functioning, such as TEMs. Other modeling efforts have demonstrated that the classical growing-degree-day approach, based on the calculation of temperature sums above a given threshold (e.g., $+5^{\circ} \mathrm{C}$ ) from a given date (e.g., Jan. 1), is not a good predictor of the onset of cambium activity (Seo et al. 2008; Prislan et al. 2013; Takahashi and Koike 2014) unless parameters are fit to the data (David 2011; N. Delpierre, unpublished results). Less attention has been paid to the modeling of the ending of xylogenesis, though the use of temperature, soil water (Deleuze and Houllier 1998), and photoperiod thresholds (Vaganov et al. 2006) have been proposed.

There is a clear need for the development of models of wood phenology in order to (1) evaluate and quantify the influence of putative environmental cues and to (2) refine models of tree and ecosystem functioning (e.g., TEMs) with accurate simulations of the occurrence of transition phases in wood formation. Such an effort could be based on both (1) the increasing amount of xylem phenology data (Rossi et al. 2008) and (2) the conceptual framework (e.g., Eq. 1) and model-fitting methods (e.g., Chuine et al. 1998; Migliavacca et al. 2012) already in use for leaf phenology.

\subsection{How can we improve phenological models?}

The vast majority of the research effort on phenological modeling has been concentrated on the simulation of the timing of leafing and flowering. There are certainly ways of improving the confidence we have in the projections of these phenological models. Good practices include the evaluation of uncertainties related to the model structure, climate scenario, and observational data, which is straightforward using a Bayesian modeling framework (Migliavacca et al. 2012). We further advocate the systematic evaluation of the ability of a model to predict past trends (see Delpierre et al. 2009a) using long-term (e.g., 100-year) datasets (e.g., from the Pan European Phenological database, www.pep725.eu).
A clear issue in the modeling of phenological events is that models describe continuous phenomena (e.g., the daily state of bud development, termed $S_{n, t}$ in Eq. 1), whereas the majority of observations are discrete units of time (dates) and correspond to the final stage of the modeled phenomenon (e.g., the date of budburst). This discrepancy has important consequences for model parameterizations. For example, in budburst phenological models, the parameterization of the endodormancy phase has been demonstrated to be inaccurate when there is no information on dormancy break used in the parameterization (Chuine et al., Can phenological models predict tree phenology accurately in the future? The unrevealed hurdle of dormancy break, under review), likely contributing to the commonly observed lower performances of two-phase models compared to simpler onephase (thermal time) models (Linkosalo et al. 2006; Vitasse et al. 2011). This problem highlights the limitations of using statistical inferences of parameter estimates in models for which measurements of parameter values should be favored whenever possible (Chuine et al. 2013). In other words, phenological models of leafing and flowering are currently "fitted beyond their means", resulting in a lack of parameter identifiability (Clark et al. 2014), which raises further concerns regarding their applicability to a warming climate scenario. For this reason, the current strategy of model development is the consideration of recent advances in the cellular biology, molecular biology, ecophysiology, and bioclimatology of phenological processes to build models that are more deeply rooted in biological reality. This approach also allows for the identification of measureable parameters, or at least parameters with clear biological meanings (Caffarra et al. 2011a; Charrier et al. 2011).

Another clear need identified from this review is a better incorporation of the dependencies among the various phenological phases that occur throughout the year. In particular, the environmental conditions during summer and early autumn have been demonstrated to impact the timing of budburst and flowering the following spring (Sanz-Pérez and Castro-Díez 2010; Misson et al. 2011). However, scarce effort has been directed at modeling the induction of dormancy, which is tightly linked to leaf senescence and cold acclimation and, further, impacts spring phenophases. Another example is the partial dependence of leaf senescence on the timing of budburst (Fu et al. 2014), which has not been implemented in models to date (but see Keenan and Richardson 2015). This situation indicates the need for a common framework that is representative of the cyclic nature of phenological events (Figs. 1, 2, and 3) and can be translated into integrated organ-scale phenological models for the entire annual cycle (Hänninen and Kramer 2007).

There is an open research field for the design and testing of models aimed at simulating the phenological cycles of wood and fine roots as well as the maturation of fruits and cones. Studies on these subjects have lagged behind those of leaves because of the difficulty of acquiring the appropriate data. Whereas the problem is far from being solved for fine roots, 
we are confident that recent advances in the understanding of seasonal wood formation will promptly be transferred into process-based models of wood formation with sound representations of the main phenophases. The constitution of phenological databases for wood (Rossi et al. 2013) will help in this effort, as will the joint analysis of leaf phenological imagery data and seasonal tree circumference data that have been initiated in continental flux tower networks (Integrated Carbon Observation system, ICOS, http://www.icosinfrastructure.eu/, and the National Earth Observation System, NEON, http://www.neoninc.org/).

\subsection{Modeling the phenology of growth in terrestrial ecosystem models}

Terrestrial ecosystem models (TEMs) have been designed to evaluate the impacts of climate variability on the elementary cycles of carbon, water, and nutrients. This class of models encompasses various degrees of details in the mechanistic description of tree and ecosystem functioning (e.g., Keenan et al. 2012) and is applied from the forest stand to the global scale. TEMs pay considerable attention to the simulation of carbon fluxes between the ecosystem and the atmosphere and, accordingly, to the representation of photosynthesis, with a strong influence of leaf phenology. Other processes, such as the seasonal growth of non-leafy organs (typically considered in the form of "wood" and "roots" compartments and, more rarely, including a "fruits" compartment) and the use of C and $\mathrm{N}$ reserves, are represented in a simpler manner, with low levels of process description. Two main approaches for the simulation of growth can be distinguished (Fig. 4, Table 1). A first approach (1) consists of simulating the growth of organs as a fraction (termed "allocation coefficient"; Fig. 4a) of daily net primary productivity (NPP). In its simplest formulation, this approach adopts a specific allocation coefficient to each model compartment (i.e., organ), set as constant throughout the carbon-gaining season (i.e., when NPP $>0$ ), implying that all organs display the same phenology of growth (Abramoff and Finzi 2014), which ultimately depends on the leaf phenology because it drives the NPP pattern. In refined representations, growth phases are specified for each organ (e.g., distinguishing sequential or parallel growth patterns for leaves, wood and roots; Table 1). Transitions from one phase to the next are arbitrarily set at given dates or depend on priority rules (e.g., leaves have priority over other organs). To date, very few TEMs distinguish these phases according to specific modules of growth phenology for non-leafy organs. In a second approach (2), the sink-force seasonality of organs is key because growth is not $\mathrm{C}$-source driven anymore. Every assimilated $\mathrm{C}$ atom is transiently stored in a "labile" storage pool and then possibly allocated to organ growth (Fig. 4b). Here, the phenology of leaves is again specifically simulated (Table 1). The growth of non-leafy organs is modulated by both allometric functions that insure functional equilibria among organs and a direct environmental control realized through temperature response functions. We know of no case in which there is a detailed representation of the growth phenologies of each organ (e.g., in all cases, the temperature responses apply throughout the year, with no distinction between phenological phases, are arbitrarily set, and are identical for all organs).

In both approaches, there is room for improving the seasonality of simulated organ growth through (1) the development of organ-specific growth phenology models, such as those commonly used for leaves, and (2) the incorporation of organ-specific temperature response functions (such as those identified for wood and roots; section 2.2 "The phenology of wood formation" and section 2.3 "The phenology of fine roots") to modulate the sink forces of organs. Such improved representations of the seasonality of organ growth in TEMs are required for addressing the relative influences of C-source (photosynthesis) and C-demand (respiration, organ sink-force, reserve formation) forces in determining tree growth (Schiestl-Aalto et al. 2015) as well as survival and reproductive success. A more detailed representation of organs in TEMs may further require (for those TEMs not considering tree species but, rather, plant functional types) the definition of subclasses within the "Deciduous Broadleaf Forest" category (i.e., separating ring-porous from diffuse-porous species, which exhibit different timings of phases of leaf and wood phenology; see "The phenology of carbon and nitrogen reserves" section).

Errors and uncertainties associated with the simulation of leaf phenology have a clear impact on the simulated GPP (White et al. 1999; Migliavacca et al. 2012) and NPP (Kramer et al. 2000; Rötzer et al. 2004), but, to our knowledge, a detailed evaluation of the influence of the combined representation of the phenologies of specific organ growth in TEMs is still missing. Preliminary tests indicate that the phenology of organ growth has a clear influence on the simulated seasonal $\mathrm{C}$ allocation pattern (Fig. 5a) and the simulated stand carbon balance (Fig. 5b). Though the mean annual error introduced by neglecting the interannual variability of organ phenology is relatively low (representing only a few percent of the annual NPP; Fig. 5b), it may influence the longer-term simulation of tree growth and survival.

\section{Conclusion}

Tree phenology is under strong environmental control. Beyond its well-documented influence on the phenology of leaves, temperature is a key driver of the phenologies of all tree organs (leaves and reproductive structures, wood, roots, 


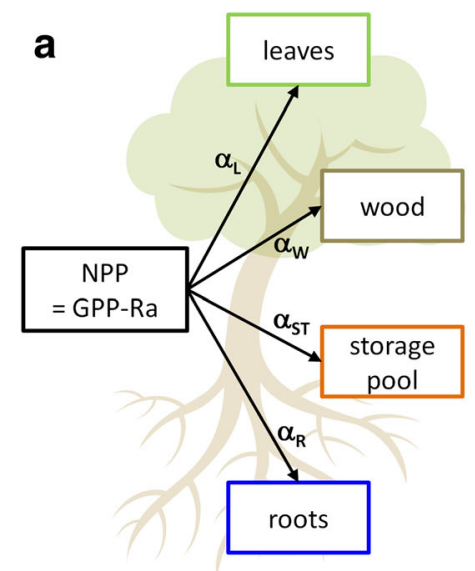

Fig. 4 Carbon allocation schemes incorporated in most terrestrial ecosystem models (TEMs). a TEMs that include an "NPP allocation scheme" (Table 1) simulate organ growth as a daily fraction (termed the "allocation coefficient", $\alpha_{i}$, dimensionless) of NPP (net primary production). The NPP is the difference between GPP (gross primary production) and $\mathrm{Ra}$ (autotrophic respiration) and can be regarded as the

reserve compounds) in the temperate and boreal climate zones.

Based on over 50 years of intense research and hundreds of published papers, our understanding of the processes and drivers of spring leaf and flowering phenology is well advanced, though still incomplete. For instance, the role of

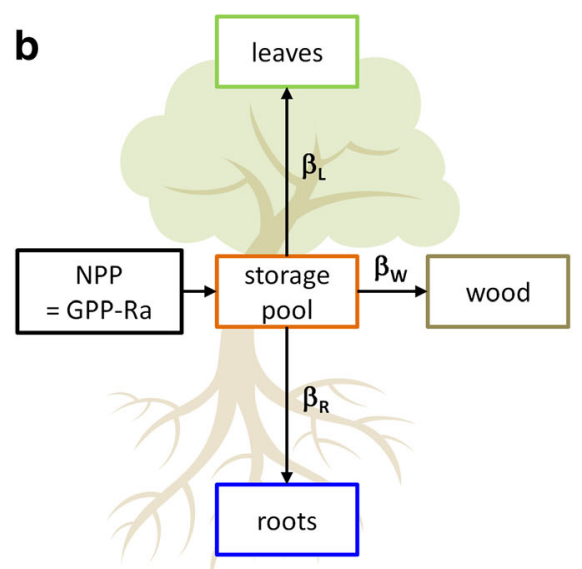

carbon supply available for growth. Growth is thus driven by the carbon source. b TEMs that include a "labile pool allocation scheme" (Table 1) do not rely directly on NPP to simulate organ growth. Rather, the growth of each organ is a flux ( $\beta_{i}$, in grams of carbon per day), representing the sink force of each organ

temperature and photoperiod on the progress of bud dormancy must be experimentally disentangled. Further research is also required to evaluate more precisely the impact of environmental drivers on the seasonal development of fruits and cones. The impacts of water stress, notably, must be confirmed and precisely quantified. All of these potential drivers should be
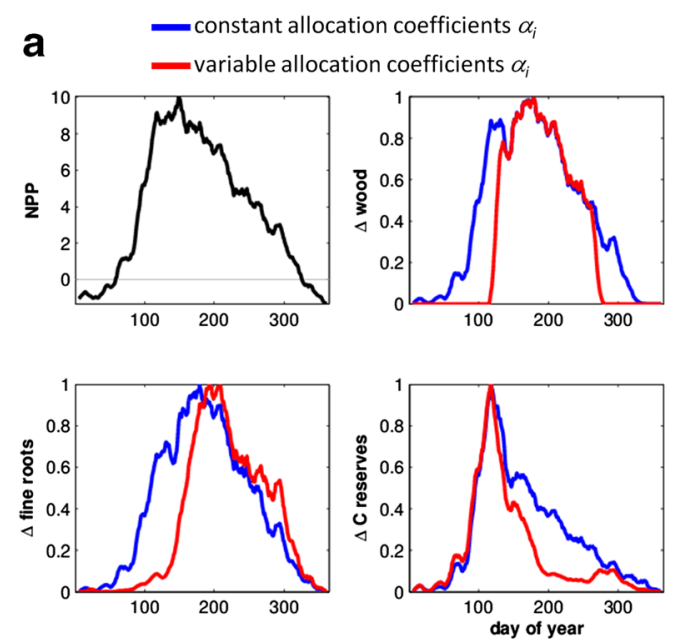

Fig. 5 The simulations of a terrestrial ecosystem model (TEM) are impacted by the modeling of organ growth phenology. We used the CASTANEA model (Table 1) as a study case. a The phenology of organ growth determines the allocation pattern. The model was used to simulate the net primary productivity (NPP) and organ growth $(\Delta)$ in a temperate spruce forest (Tharandt forest) over the 1997-2002 period. Wood and fine root growth were simulated using a constant allocation coefficient throughout the season (blue) or with variable coefficients resulting from phenology modeling (red). When simulating the organ phenology, root growth was interrupted at low soil temperatures, following Alvarez-Uria and Körner (2007). The seasonality of wood growth was simulated using a thermal time model fit on observed data for Picea mariana and Picea abies (N. Delpierre, unpublished results). In

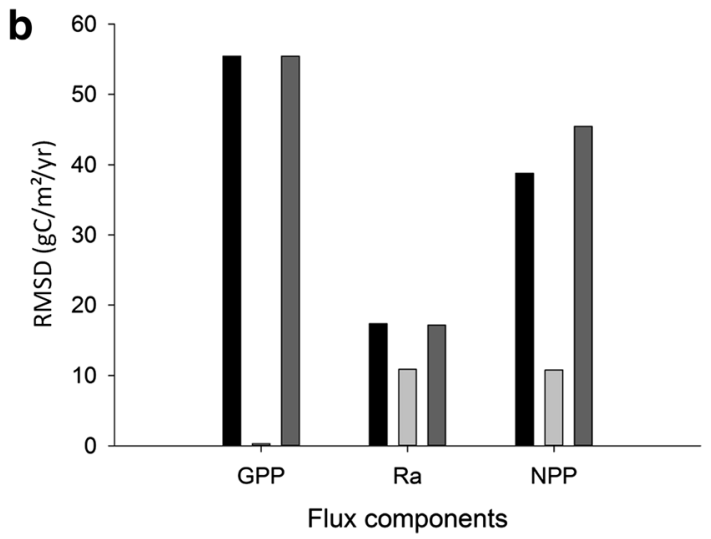

$L-C-/ L+C-=$ Influence of the variability of leaf phenology

$\mathrm{L}+\mathrm{C}-/ \mathrm{L}+\mathrm{C}+=$ Influence of the variability of cambium phenology

$\mathrm{L}-\mathrm{C}-/ \mathrm{L}+\mathrm{C}+=$ Influence of the combined variability of leaf and cambium phenology

all cases, allocation to the $\mathrm{C}$ reserve pool was the resultant. b The phenology of organ growth impacts the carbon fluxes simulated in a temperate oak forest (Barbeau forest) for the 2006-2013 period. The impact was quantified as the root mean square difference (RMSD) between fluxes simulated with leaf (L) and cambium (C) phenology modules turned on $(+)$ or off $(-)$. For example, the black bars represent the RMSD calculated between fluxes simulated with both leaf and cambium phenology turned off $(\mathrm{L}-\mathrm{C}-$, i.e., the dates of leafing and spring cambium onset are forced to the observed mean values) and the fluxes calculated with the leaf phenology module turned on $(\mathrm{L}+\mathrm{C}-$, i.e., the date of leafing varies from year to year and the date of cambium onset is forced to the observed mean value). $\mathrm{GPP}=$ gross primary production, $\mathrm{Ra}=$ autotrophic respiration, $\mathrm{NPP}=$ net primary production 
encapsulated into novel, comprehensive models that consider the entire ontogenetic program of development from bud-set to leaf senescence or fruit/seed ripening.

The impacts of environmental drivers on the phenology of wood and roots clearly need to be addressed more precisely. The accumulation of observational data on wood phenology will help to fill gaps in our understanding of the ending phases of the wood formation cycle. Although spring phases of wood formation are very likely under temperature control, accurate models for the prediction of the onset of wood formation are still lacking. Similar to leaf phenology, a complete model of wood formation should incorporate constraints relative to the ontogenetic development of wood. The constitution of databases of the key phenological stages of wood formation will help in this task (Rossi et al. 2013).

The phenology of fine root elongation and mortality remains difficult to elucidate. However, information regarding the dependence of root growth and mortality on soil temperature and moisture exist and could easily be incorporated into forest models, which usually neglect such influences.

A sound assessment of the impact of climate change on tree integrated functioning requires the precise characterization of the phenology of the multiple tree organs. We still have a very limited comprehension of the internal dynamics of tree carbon and nutrient resources. If storage is indeed an active process, then we must be able to identify precisely the internal and environmental drivers of storage throughout the year. Another aspect that deserves thorough attention is the interdependence of organ phenology. The extent to which climate change might impact the relative timing of organ phenophases is a key, yet unresolved question.

We believe that these research avenues will help to develop more mechanistic and integrated models of tree phenology. We expect these refined phenological models to improve the predictions of TEMs and, consequently, allow for a more precise evaluation of the impact of climate change on temperate and boreal forest ecosystems.

Acknowledgments We thank Eric Dufrêne and Laure Barthes for insightful discussions during the preparation of the manuscript.

Open Access This article is distributed under the terms of the Creative Commons Attribution License which permits any use, distribution, and reproduction in any medium, provided the original author(s) and the source are credited.

\section{References}

Abramoff RZ, Finzi AC (2014) Are above- and below-ground phenology in sync? New Phytol. doi:10.1111/nph.13111

Alberto FJ, Aitken SN, Alía R et al (2013) Potential for evolutionary responses to climate change-evidence from tree populations. Glob Chang Biol 19:1645-1661. doi:10.1111/gcb.12181
Aloni R (2013) The role of hormones in controlling vascular differentiation. In: Fromm J (ed) Cell. Asp. Wood Form. Springer Berlin Heidelberg, Berlin, Heidelberg, pp 99-139

Alvarez-Uria P, Körner C (2007) Low temperature limits of root growth in deciduous and evergreen temperate tree species. Funct Ecol 21: 211-218. doi:10.1111/j.1365-2435.2007.01231.x

Aono Y, Kazui K (2008) Phenological data series of cherry tree flowering in Kyoto, Japan, and its application to reconstruction of springtime temperatures since the 9th century. 914:905-914. doi: 10.1002/joc

Archetti M, Richardson AD, O'Keefe J, Delpierre N (2013) Predicting climate change impacts on the amount and duration of autumn colors in a New England forest. PLoS ONE 8:e57373. doi:10. 1371/journal.pone.0057373

Arora R, Rowland LJ, Tanino K (2003) Induction and release of bud dormancy in woody perennials: a science comes of age. HortScience 38(5):911-921

Arora VK, Boer GJ (2005) A parameterization of leaf phenology for the terrestrial ecosystem component of climate models. Glob Chang Biol 11:39-59. doi:10.1111/j.1365-2486.2004.00890.x

Augspurger CK, Bartlett EA (2003) Differences in leaf phenology between juvenile and adult trees in a temperate deciduous forest. Tree Physiol 23:517-525. doi:10.1093/treephys/23.8.517

Badeck F-W, Bondeau A, Bottcher K et al (2004) Responses of spring phenology to climate change. New Phytol 162:295-309. doi:10. 1111/j.1469-8137.2004.01059.x

Barbaroux C, Bréda N (2002) Contrasting distribution and seasonal dynamics of carbohydrate reserves in stem wood of adult ring-porous sessile oak and diffuse-porous beech trees. Tree Physiol 22(17): $1201-1210$

Barbaroux C, Breda N, Dufrene E (2003) Distribution of above-ground and below-ground carbohydrate reserves in adult trees of two contrasting broad-leaved species (Quercus petraea and Fagus sylvatica). New Phytol 157:605-615. doi:10.1046/j.1469-8137.2003.00681.x

Barr AG, Black TA, Hogg EH et al (2004) Inter-annual variability in the leaf area index of a boreal aspen-hazelnut forest in relation to net ecosystem production. Agric For Meteorol 126:237-255. doi:10. 1016/j.agrformet.2004.06.011

Basler D, Körner C (2014) Photoperiod and temperature responses of bud swelling and bud burst in four temperate forest tree species. Tree Physiol 34:377-388

Bazot S, Barthes L, Blanot D, Fresneau C (2013) Distribution of nonstructural nitrogen and carbohydrate compounds in mature oak trees in a temperate forest at four key phenological stages. Trees 27:10231034. doi:10.1007/s00468-013-0853-5

Begum S, Nakaba S, Oribe Y et al (2007) Induction of cambial reactivation by localized heating in a deciduous hardwood hybrid poplar (Populus sieboldii $\times$ P. grandidentata). Ann Bot 100:439-447. doi:10.1093/aob/mcm130

Begum S, Nakaba S, Oribe Y et al (2010) Cambial sensitivity to rising temperatures by natural condition and artificial heating from late winter to early spring in the evergreen conifer Cryptomeria japonica. Trees 24:43-52. doi:10.1007/s00468-009-0377-1

Begum S, Nakaba S, Yamagishi Y et al (2013) Regulation of cambial activity in relation to environmental conditions: understanding the role of temperature in wood formation of trees. Physiol Plant 147: 46-54. doi:10.1111/j.1399-3054.2012.01663.x

Begum S, Shibagaki M, Furusawa O et al (2012) Cold stability of microtubules in wood-forming tissues of conifers during seasons of active and dormant cambium. Planta 235:165-179. doi:10.1007/s00425011-1500-2

Bergh J, McMurtrie RE, Linder S (1998) Climatic factors controlling the productivity of Norway spruce: a model-based analysis. For Ecol Manag 110:127-139. doi:10.1016/S0378-1127(98)00280-1

Burke M, Raynal D (1994) Fine root growth phenology, production, and turnover in a northern hardwood forest ecosystem. Plant Soil 162: $135-146$ 
Caffarra A, Donnelly A, Chuine I (2011a) Modelling the timing of Betula pubescens budburst. II. Integrating complex effects of photoperiod into process-based models. Clim Res 46:159-170. doi:10.3354/ cr00983

Caffarra A, Donnelly A, Chuine I, Jones MB (2011b) Modelling the timing of Betula pubescens budburst. I. Temperature and photoperiod: a conceptual model. Clim Res 46:147-157. doi:10.3354/ cr00980

Campbell R, Sugano A (1975) Phenology of bud burst in Douglas-fir related to provenance, photoperiod, chilling, and flushing temperature. Bot Gaz 290-298

Chaffey N (2013) Secondary growth of tree roots: cytoskeletal perspectives. In: Eshel A, Beeckman T (eds) Roots hidden half. Boca Raton, p 831

Charrier G, Bonhomme M, Lacointe A, Améglio T (2011) Are budburst dates, dormancy and cold acclimation in walnut trees (Juglans regia L.) under mainly genotypic or environmental control? Int J Biometeorol 55:763-774. doi:10.1007/s00484-011-0470-1

Chuine I (2010) Why does phenology drive species distribution? Philos Trans R Soc Lond B Biol Sci 365:3149-3160. doi:10.1098/rstb. 2010.0142

Chuine I, Beaubien EG (2001) Phenology is a major determinant of tree species range. Ecol Lett 4:500-510. doi:10.1046/j.1461-0248.2001. 00261.x

Chuine I, Cour P, Rousseau DD (1998) Fitting models predicting dates of flowering of temperate-zone trees using simulated annealing. Plant Cell Environ 21:455-466. doi:10.1046/j.1365-3040.1998.00299.x

Chuine I, Garcia de Cortazar-atauri I, Kramer K, Hänninen H (2013) Plant development models. In: Schwartz MD (ed) Phenol. an Integr. Environ. Sci., 2nd edn. Springer, Dordrecht, pp 275-293

Chuine I, Morin X, Bugmann H (2010) Warming, photoperiods, and tree phenology. Science 329:277-278, 80-

Chuine I, Yiou P, Viovy N et al (2004) Historical phenology: grape ripening as a past climate indicator. Nature 432:289-290. doi:10.1038/ 432289 a

Clark JS, Salk C, Melillo J, Mohan J (2014) Tree phenology responses to winter chilling, spring warming, at north and south range limits. Funct Ecol. doi:10.1111/1365-2435.12309

Cochard H, Tyree MT (1990) Xylem dysfunction in Quercus: vessel sizes, tyloses, cavitation and seasonal changes in embolism. Tree Physiol 6:393-407. doi:10.1093/treephys/6.4.393

Cooke JEK, Eriksson ME, Junttila O (2012) The dynamic nature of bud dormancy in trees: environmental control and molecular mechanisms. Plant Cell Environ 35:1707-1728. doi:10.1111/j.13653040.2012.02552.x

Coville FV (1920) The influence of cold in stimulating the growth of plants. Proc Natl Acad Sci U S A 434-435. doi: 10.1175/15200493(1920)48<643b:TIOCIS >2.0.CO;2

Čufar K, Prislan P, de Luis M, Gričar J (2008) Tree-ring variation, wood formation and phenology of beech (Fagus sylvatica) from a representative site in Slovenia, SE Central Europe. Trees 22:749-758. doi:10.1007/s00468-008-0235-6

Cuny HE, Rathgeber CBK, Lebourgeois F et al (2012) Life strategies in intra-annual dynamics of wood formation: example of three conifer species in a temperate forest in north-east France. Tree Physiol 32: 612-625. doi:10.1093/treephys/tps039

Dahl Å, Langvall O (2008) Observations of phenology in Sweden — past and present. In: Nekovar J, Koch E, Kubin E, et al. (eds) Hist. Curr. status plant Phenol. Eur. COST Office, Brussels, pp 161-165

Damesin C, Lelarge C (2003) Carbon isotope composition of current-year shoots from Fagus sylvatica in relation to growth, respiration and use of reserves. Plant Cell Environ 26:207-219. doi:10.1046/j.13653040.2003.00951.x

Dantec CF, Vitasse Y, Bonhomme M et al (2014) Chilling and heat requirements for leaf unfolding in European beech and sessile oak populations at the southern limit of their distribution range. Int $\mathrm{J}$ Biometeorol 58:1853-1864. doi:10.1007/s00484-014-0787-7

David A (2011) Modélisation de la croissance ligneuse chez le Hêtre et le Chêne sessile. Master's thesis dissertation. Université Paris-Sud. 43 pp

De Barba D, Rossi S, Deslauriers A, Morin H (2015) Effects of soil warming on nitrogen foliar applications on bud burst of black spruce. Trees. doi:10.1007/s00468-015-1152-0

Deckmyn G, Evans SP, Randle TJ (2006) Refined pipe theory for mechanistic modeling of wood development. Tree Physiol 26:703-717. doi:10.1093/treephys/26.6.703

Deckmyn G, Verbeeck H, Op de Beeck M et al (2008) ANAFORE: a stand-scale process-based forest model that includes wood tissue development and labile carbon storage in trees. Ecol Model 215: 345-368. doi:10.1016/j.ecolmodel.2008.04.007

Delaporte A (2010) Le carbone assimilé par les feuilles de Charme (Carpinus betulus L.) est-il alloué aux réserves en début de saison de végétation? Master's thesis dissertation. Université Paris-Sud. 37 $\mathrm{pp}$

Deleuze C, Houllier F (1998) A simple process-based xylem growth model for describing wood microdensitometric profiles. J Theor Biol 193:99-113

Delpierre N, Dufrêne E, Soudani K et al (2009a) Modelling interannual and spatial variability of leaf senescence for three deciduous tree species in France. Agric For Meteorol 149:938-948. doi:10.1016/ j.agrformet.2008.11.014

Delpierre N, Soudani K, François C et al (2009b) Exceptional carbon uptake in European forests during the warm spring of 2007: a data-model analysis. Glob Chang Biol 15:1455-1474. doi:10. 1111/j.1365-2486.2008.01835.x

Delpierre N, Soudani K, François C et al (2012) Quantifying the influence of climate and biological drivers on the interannual variability of carbon exchanges in European forests through process-based modelling. Agric For Meteorol 154-155:99-112. doi:10.1016/j. agrformet.2011.10.010

Demarée GR, Rutishauser T (2011) From "Periodical Observations" to "Anthochronology" and "Phenology"- the scientific debate between Adolphe Quetelet and Charles Morren on the origin of the word "Phenology". Int J Biometeorol 55:753-761. doi:10.1007/ s00484-011-0442-5

Denne M, Dodd R (1981) The environmental control of xylem differentiation. In: Barnett JR (ed) Xylem cell Dev. Castle House Publications, Tunbridge Wells, pp 236-255

Dietze MC, Sala A, Carbone MS et al (2014) Nonstructural carbon in woody plants. Annu Rev Plant Biol 65:667-687. doi:10.1146/ annurev-arplant-050213-040054

Donnelly A, Caffarra A, O'Neill BF (2011) A review of climate-driven mismatches between interdependent phenophases in terrestrial and aquatic ecosystems. Int J Biometeorol 55:805-817. doi:10.1007/ s00484-011-0426-5

Dougherty PM, Whitehead D, Vose JM (1994) Environmental influences on the phenology of pine. Ecol Bull 43:64-75

Dufour B, Morin H (2010) Tracheid production phenology of Picea mariana and its relationship with climatic fluctuations and bud development using multivariate analysis. Tree Physiol 30:853-865. doi:10.1093/treephys/tpq046

Dufrêne E, Davi H, François C et al (2005) Modelling carbon and water cycles in a beech forest. Ecol Model 185:407-436. doi:10.1016/j. ecolmodel.2005.01.004

Dünisch O, Bauch J (1994) Influence of soil substrate and drought on wood formation of spruce (Picea abies Karst.) under controlled conditions. Holzforschung-Int J Biol Chem Phys Technol Wood 48:447-457

Eissenstat DM, McCormack ML, Du Q (2013) Global change and root lifespan. In: Eshel A, Beeckman T (eds) Roots Hidden Half. CRC Press, Boca Raton, p 831 
El Zein R, Maillard P, Bréda N et al (2011) Seasonal changes of C and N non-structural compounds in the stem sapwood of adult sessile oak and beech trees. Tree Physiol 31:843-854. doi:10.1093/treephys/ tpr074

Estiarte M, Peñuelas J (2014) Alteration of the phenology of leaf senescence and fall in winter deciduous species by climate change: effects on nutrient proficiency. Glob Chang Biol. doi:10.1111/gcb.12804

Estrella N, Menzel A (2006) Responses of leaf colouring in four deciduous tree species to climate and weather in Germany. Clim Res 32: 253-267

Fatichi S, Leuzinger S, Körner C (2014) Moving beyond photosynthesis: from carbon source to sink-driven vegetation modeling. New Phytol 201:1086-1095. doi:10.1111/nph.12614

Fischer C, Höll W (1991) Food reserves of Scots pine (Pinus sylvestris L.) I. Seasonal changes in the carbohydrate and fat reserves of pine needles. Trees 5:187-195

Fischer C, Höll W (1992) Food reserves of scots pine (Pinus sylvestris L.) II. Seasonal changes and radial distribution of carbohydrate and fat reserves in pine wood. Trees 6:147-155

Fonti P, Solomonoff N, García-González I (2007) Earlywood vessels of Castanea sativa record temperature before their formation. New Phytol 173:562-570

Frankenstein C, Eckstein D, Schmitt U (2005) The onset of cambium activity - a matter of agreement? Dendrochronologia 23:57-62. doi:10.1016/j.dendro.2005.07.007

Fu YSH, Campioli M, Vitasse Y et al (2014) Variation in leaf flushing date influences autumnal senescence and next year's flushing date in two temperate tree species. Proc Natl Acad Sci U S A 111:73557360. doi:10.1073/pnas.1321727111

Fujii S (1993) Studies on acorn production and seed predation in Quercus serrata - growth, falling phenology, estimation of production, and insect seed predators. Bull Osaka Mus Nat Hist 47:1-17

Garcia de Cortazar-Atauri I, Brisson N, Ollat N et al (2009) Asynchronous dynamics of grapevine (Vitis vinifera) maturation: experimental study for a modeling approach. J Int des Sci la Vigne du Vin 43:83-97

Gaul D, Hertel D, Borken W et al (2008) Effects of experimental drought on the fine root system of mature Norway spruce. For Ecol Manag 256:1151-1159. doi:10.1016/j.foreco.2008.06.016

Geßler A, Kreuzwieser J, Dopatka T, Rennenberg H (2002) Diurnal courses of ammonium net uptake by the roots of adult beech (Fagus sylvatica) and spruce (Picea abies) trees. Plant Soil 240: 23-32. doi:10.1023/A:1015831304911

Gilson A, Barthes L, Delpierre N et al (2014) Seasonal changes in carbon and nitrogen compound concentrations in a Quercus petraea chronosequence. Tree Physiol 34:716-729. doi:10.1093/treephys/ tpu060

Gomez L, Faurobert M (2002) Contribution of vegetative storage proteins to seasonal nitrogen variations in the young shoots of peach trees (Prunus persica L. Batsch). J Exp Bot 53:2431-2439. doi:10.1093/ jxb/erf098

González-González BD, García-González I, Vázquez-Ruiz RA (2013) Comparative cambial dynamics and phenology of Quercus robur L. and Q. pyrenaica Willd. in an Atlantic forest of the northwestern Iberian Peninsula. Trees 27:1571-1585. doi:10.1007/s00468-0130905-x

Goulden ML, Munger JW, Fan S et al (1996) Exchange of carbon dioxide by a deciduous forest : response to interannual climate variability. Science 271:576-578

Greer DH, Wünsche JN, Norling CL, Wiggins HN (2005) Root-zone temperatures affect phenology of bud break, flower cluster development, shoot extension growth and gas exchange of "Braeburn" (Malus domestica) apple trees. Tree Physiol 26:105-111

Gričar J (2010) Xylem and phloem formation in Sessile Oak from Slovenia in 2007. Wood Res 55:15-22
Gričar J, Čufar K (2008) Seasonal dynamics of phloem and xylem formation in silver fir and Norway spruce as affected by drought. Russ J Plant Physiol 55:538-543. doi:10.1134/S102144370804016X

Gričar J, Zupančič M, Čufar K, Oven P (2007) Regular cambial activity and xylem and phloem formation in locally heated and cooled stem portions of Norway spruce. Wood Sci Technol 41:463-475. doi:10. 1007/s00226-006-0109-2

Gruber A, Pirkebner D, Florian C, Oberhuber W (2012) No evidence for depletion of carbohydrate pools in Scots pine (Pinus sylvestris L.) under drought stress. Plant Biol 14:142-148. doi:10.1111/j.14388677.2011.00467.x

Gruber A, Strobl S, Veit B, Oberhuber W (2010) Impact of drought on the temporal dynamics of wood formation in Pinus sylvestris. Tree Physiol 30:490-501. doi:10.1093/treephys/tpq003

Guillemot J, Martin-StPaul NK, Dufrêne E et al (2015) The dynamic of annual carbon allocation to wood in European forests is consistent with a combined source-sink limitation of growth: implications for modelling. Biogeosci Discuss 12:2213-2255. doi:10.5194/bgd-122213-2015

Guo D, Xia M, Wei X et al (2008) Anatomical traits associated with absorption and mycorrhizal colonization are linked to root branch order in twenty-three Chinese temperate tree species. New Phytol 180:673-683. doi:10.1111/j.1469-8137.2008.02573.x

Gyllenstrand N, Clapham D, Källman T, Lagercrantz U (2007) A Norway spruce FLOWERING LOCUS T homolog is implicated in control of growth rhythm in conifers. Plant Physiol 144:248-257. doi:10. 1104/pp. 107.095802

Hanes JM, Richardson AD, Klosterman S (2013) Mesic temperate deciduous forest phenology. In: Schwartz MD (ed) Phenol. an Integr. Environ. Sci., 2nd edn. Springer, Dordrecht, p 610

Hänninen H (1990) Modelling bud dormancy release in trees from cool and temperate regions. Acta For Fenn 213:3-47

Hänninen H, Kramer K (2007) A framework for modelling the annual cycle of trees in boreal and temperate. Silva Fenn 41:167-205

Hänninen H, Tanino K (2011) Tree seasonality in a warming climate. Trends Plant Sci 16:412-416. doi:10.1016/j.tplants.2011.05.001

Harrington CA, Gould PJ, St.Clair JB (2010) Modeling the effects of winter environment on dormancy release of Douglas-fir. For Ecol Manag 259:798-808. doi:10.1016/j.foreco.2009.06.018

Hartmann H, Ziegler W, Trumbore S (2013) Lethal drought leads to reduction in nonstructural carbohydrates in Norway spruce tree roots but not in the canopy. Funct Ecol 27:413-427. doi:10.1111/13652435.12046

Heide O (1993) Daylength and thermal time responses of budburst during dormancy release in some northern deciduous trees. Physiol Plant $88: 531-540$

Heide OM (2011) Temperature rather than photoperiod controls growth cessation and dormancy in Sorbus species. J Exp Bot 62:53975404. doi:10.1093/jxb/err213

Hendrick RL, Pregitzer KS (1992) The demography of fine roots in a northern hardwood forest. Ecology 73:1094-1104

Hmimina G, Dufrêne E, Pontailler J-Y et al (2013) Evaluation of the potential of MODIS satellite data to predict vegetation phenology in different biomes: an investigation using ground-based NDVI measurements. Remote Sens Environ 132:145-158. doi:10.1016/j. rse.2013.01.010

Hoch G (2005) Fruit-bearing branchlets are carbon autonomous in mature broad-leaved temperate forest trees. Plant Cell Environ 28:651-659. doi:10.1111/j.1365-3040.2004.01311.x

Hoch G (2015) Carbon reserves as indicators for carbon limitation in trees. In Progress in Botany (pp. 321-346). Springer International Publishing

Hoch G, Richter A, Körner C (2003) Non-structural carbon compounds in temperate forest trees. Plant Cell Environ 26:1067-1081 
Horvath DP, Anderson JV, Chao WS, Foley ME (2003) Knowing when to grow: signals regulating bud dormancy. Trends Plant Sci 8:534-540. doi:10.1016/j.tplants.2003.09.013

Huang J-G, Deslauriers A, Rossi S (2014) Xylem formation can be modeled statistically as a function of primary growth and cambium activity. New Phytol 203:831-841. doi:10.1111/nph.12859

Hwang T, Band LE, Miniat CF et al (2014) Divergent phenological response to hydroclimate variability in forested mountain watersheds. Glob Chang Biol 20:2580-2595. doi:10.1111/gcb.12556

Jalkanen R, Aalto T, Kurkela T (1995) Development of needle retention in Scots pine (Pinus sylvestris) in 1957-1991 in northern and southern Finland. Trees 10(2):125-133

Jolly WM, Nemani R, Running SW (2004) Enhancement of understory productivity by asynchronous phenology with overstory competitors in a temperate deciduous forest. Tree Physiol 24:1069-1071. doi:10.1093/treephys/24.9.1069

Jolly WM, Nemani R, Running SW (2005) A generalized, bioclimatic index to predict foliar phenology in response to climate. Glob Chang Biol 11:619-632. doi:10.1111/j.1365-2486.2005.00930.x

Joslin JD, Wolfe MH (1998) Impacts of water input manipulations on fine root production and mortality in a mature hardwood forest. Plant Soil 204(2):165-174

Joslin JD, Wolfe MH, Hanson PJ (2001) Factors controlling the timing of root elongation intensity in a mature upland oak stand. Plant Soil 228:201-212

Kalliokoski T, Mäkinen H, Jyske T et al (2013) Effects of nutrient optimization on intra-annual wood formation in Norway spruce. Tree Physiol 33:1145-1155. doi:10.1093/treephys/tpt078

Keenan TF, Baker I, Barr A et al (2012) Terrestrial biosphere model performance for inter-annual variability of land-atmosphere $\mathrm{CO}_{2}$ exchange. Glob Chang Biol 18:1971-1987. doi:10.1111/j.13652486.2012.02678.x

Keenan TF, Darby B, Felts E et al (2014) Tracking forest phenology and seasonal physiology using digital repeat photography: a critical assessment. Ecol Appl 24:1478-1489. doi:10.1890/13-0652.1

Keenan TF, Richardson AD (2015) The timing of autumn senescence is affected by the time of spring phenology: implications for predictive models. Glob Chang Biol. doi:10.1111/gcb.12890

Kikuzawa K (1991) A cost-benefit analysis of leaf habit and leaf longevity of trees and their geographical pattern. Am Nat 138:1250-1263

Kikuzawa K (1995) Leaf phenology as an optimal strategy for carbon gain in plants. Can J Bot 73:158-163

Kikuzawa K (1996) Geographical distribution of leaf life span and species diversity of trees simulated by a leaf-longevity model. Vegetatio 122:61-67

King JS, Albaugh TJ, Allen HL et al (2002) Below-ground carbon input to soil is controlled by nutrient availability and fine root dynamics in loblolly pine. New Phytol 154:389-398. doi:10.1046/j.1469-8137. 2002.00393.x

Klein T, Hoch G, Yakir D, Körner C (2014) Drought stress, growth and nonstructural carbohydrate dynamics of pine trees in a semi-arid forest. Tree Physiol 34:981-992. doi:10.1093/treephys/tpu071

Koch E (2008) History of international phenology networks. In: Nekovar J, Koch E, Kubin E, et al. (eds) Hist. Curr. status plant Phenol. Eur. COST Office, Brussels, pp 12-16

Konôpka B, Yuste JC, Janssens IA, Ceulemans R (2005) Comparison of fine root dynamics in Scots pine and Pedunculate oak in sandy soil. Plant Soil 276:33-45. doi:10.1007/s11104-004-2976-3

Koppel A, Troeng E, Linder S (1987) Respiration and photosynthesis in cones of Norway spruce (Picea abies (L.) Karst.). Trees 1:123-128

Körner C, Basler D (2010) Phenology under global warming. Science 327:1461-1462, 80-

Kramer K (1995) Modelling comparison to evaluate the importance of phenology for the effects of climate change on growth of temperatezone deciduous trees. Clim Res 5:119-130
Kramer K, Leinonen I, Loustau D (2000) The importance of phenology for the evaluation of impact of climate change on growth of boreal, temperate and Mediterranean forests ecosystems: an overview. Int J Biometeorol 44:67-75. doi:10.1007/s004840000066

Krinner G, Viovy N, de Noblet-Ducoudré N, et al. (2005) A dynamic global vegetation model for studies of the coupled atmosphere-biosphere system. Global Biogeochem Cycles 19:GB 1015. doi: 10. 1029/2003GB002199

Kuhns MR, Garrett HE, Teskey RO, Hinckley TM (1985) Root growth of black walnut trees related to soil temperature, soil water potential, and leaf water potential. For Sci 31:617-629

Lachaud S, Bonnemain J-L (1981) Xylogenèse chez les Dicotylédones arborescentes. I. Modalités de la remise en activite du cambium et de la xylogenèse chez les Hêtres et les Chênes Agés. Can J Bot 59: $1222-1230$

Lachaud S, Catesson A-M, Bonnemain J-L (1999) Structure and functions of the vascular cambium. Comptes Rendus l'Académie des Sci III-Sciences la Vie 322:633-650

Lang GA, Eearly JD, Martin GC, Darnell RL (1987) Endo-, para-, and ecodormancy: physiological terminology and classification for dormancy research. HortSci 22:371-377

Laube J, Sparks TH, Estrella N et al (2014) Chilling outweighs photoperiod in preventing precocious spring development. Glob Chang Biol 20:170-182. doi:10.1111/gcb.12360

Lebourgeois F, Pierrat J-C, Perez V et al (2010) Simulating phenological shifts in French temperate forests under two climatic change scenarios and four driving global circulation models. Int J Biometeorol 54: 563-581. doi:10.1007/s00484-010-0305-5

Leuschner C, Backes K, Hertel D et al (2001) Drought responses at leaf, stem and fine root levels of competitive Fagus sylvatica L. and Quercus petraea (Matt.) Liebl. trees in dry and. For Ecol Manag 149:33-46

Levins R (1966) The strategy of model building in population biology. Am Sci 54:421-431

Linder S, Troeng E (1981) The seasonal course of respiration and photosynthesis in strobuli of Scots pine (Pinus sylvestris L.). For Sci 27: 267-276

Linkosalo T, Häkkinen R, Hänninen H (2006) Models of the spring phenology of boreal and temperate trees: is there something missing? Tree Physiol 26:1165-1172

Linkosalo T, Häkkinen R, Terhivuo J et al (2009) The time series of flowering and leaf bud burst of boreal trees (1846-2005) support the direct temperature observations of climatic warming. Agric For Meteorol 149:453-461. doi:10.1016/j.agrformet.2008.09.006

Little CHA, Bonga JM (1974) Rest in the cambium of Abies balsamea. Can J Bot 52:1723-1730

Lupi C, Morin H, Deslauriers A, Rossi S (2010) Xylem phenology and wood production: resolving the chicken-or-egg dilemma. Plant Cell Environ 33:1721-1730. doi:10.1111/j.1365-3040.2010.02176.x

Lyr H, Hoffmann G (1967) Growth rates and growth periodicity of tree roots. Int Rev For Res 2:181-236

McCormack ML, Adams TS, Smithwick EAH, Eissenstat DM (2014) Variability in root production, phenology, and turnover rate among 12 temperate tree species. Ecology 95:2224-2235

Medvigy D, Wofsy SC, Munger JW et al (2009) Mechanistic scaling of ecosystem function and dynamics in space and time: Ecosystem Demography model version 2. J Geophys Res 114:G01002. doi: 10.1029/2008JG000812

Mellerowicz EJ, Coleman WK, Riding RT, Little CHA (1992) Periodicity of cambial activity in Abies balsamea. 1. Effects of temperature and photoperiod on cambial dormancy and frost hardiness. Physiol Plant 85:515-525

Menzel A (2013) Phenological data, networks and research: Europe. In: Schwartz MD (ed) Phenol. an Integr. Environ. Sci., 2nd edn. Springer, Dordrecht, p 610 
Menzel A, Sparks TH, Estrella N et al (2006) European phenological response to climate change matches the warming pattern. Glob Chang Biol 12:1969-1976. doi:10.1111/j.1365-2486.2006.01193.x

Meunier C, Sirois L, Bégin Y (2007) Climate and Picea mariana seed maturation relationships: a multi-scale perspective. Ecol Monogr 77: 361-376. doi:10.1890/06-1543.1

Michelot A, Simard S, Rathgeber C et al (2012) Comparing the intraannual wood formation of three European species (Fagus sylvatica, Quercus petraea and Pinus sylvestris) as related to leaf phenology and non-structural carbohydrate dynamics. Tree Physiol 32:10331045. doi:10.1093/treephys/tps052

Migliavacca M, Sonnentag O, Keenan TF et al (2012) On the uncertainty of phenological responses to climate change, and implications for a terrestrial biosphere model. Biogeosciences 9:2063-2083. doi:10. 5194/bg-9-2063-2012

Millard P, Grelet G-A (2010) Nitrogen storage and remobilization by trees: ecophysiological relevance in a changing world. Tree Physiol 30:1083-1095. doi:10.1093/treephys/tpq042

Millard P, Proe MF (1992) Storage and internal cycling of nitrogen in relation to seasonal growth of Sitka spruce. Tree Physiol 10:33-43. doi:10.1093/treephys/10.1.33

Millard P, Sommerkorn M, Grelet G-A (2007) Environmental change and carbon limitation in trees: a biochemical, ecophysiological and ecosystem appraisal. New Phytol 175:11-28. doi:10.1111/j.1469-8137. 2007.02079.x

Misson L, Degueldre D, Collin C et al (2011) Phenological responses to extreme droughts in a Mediterranean forest. Glob Chang Biol 17: 1036-1048. doi:10.1111/j.1365-2486.2010.02348.x

Moser L, Fonti P, Büntgen U et al (2010) Timing and duration of European larch growing season along altitudinal gradients in the Swiss Alps. Tree Physiol 30:225-233. doi:10.1093/treephys/tpp108

Mutke S, Gordo J, Climent J, Gil L (2003) Shoot growth and phenology modelling of grafted Stone pine (Pinus pinea L.) in Inner Spain. Ann For Sci 60:527-537. doi:10.1051/forest

Myking T, Heide O (1995) Dormancy release and chilling requirement of buds of latitudinal ecotypes of Betula pendula and B. pubescens. Tree Physiol 15:697-704

Noguchi K, Sakata T, Mizoguchi T, Takahashi M (2005) Estimating the production and mortality of fine roots in a Japanese cedar (Cryptomeria japonica D. Don) plantation using a minirhizotron technique. J For Res 10:435-441. doi:10.1007/s10310-005-0163-x

Nord E, Lynch JP (2009) Plant phenology: a critical controller of soil resource acquisition. J Exp Bot 60:1927-1937. doi:10.1093/jxb/ $\operatorname{erp} 018$

Oladi R, Pourtahmasi K, Eckstein D, Bräuning A (2010) Seasonal dynamics of wood formation in Oriental beech (Fagus orientalis Lipsky) along an altitudinal gradient in the Hyrcanian forest, Iran. Trees 25:425-433. doi:10.1007/s00468-010-0517-7

Oribe Y, Funada R, Kubo T (2003) Relationships between cambial activity, cell differentiation and the localization of starch in storage tissues around the cambium in locally heated stems of Abies sachalinensis (Schmidt) Masters. Trees 17:185-192. doi:10.1007/s00468-0020231-1

Oribe Y, Kubo T (1997) Effect of heat on cambial reactivation during winter dormancy in evergreen and deciduous conifers. Tree Physiol 17:81-87. doi:10.1093/treephys/17.2.81

Palacio S, Hoch G, Sala A et al (2014) Does carbon storage limit tree growth? New Phytol 201:1096-1100

Pallardy SG (2008) Physiology of woody plants, 3rd edn. 469 pp

Plomion C, Leprovost G, Stokes A (2001) Wood formation in trees. Plant Physiol 127:1513-1523. doi:10.1104/pp. 010816.1

Pregitzer K (2002) Fine roots of trees - a new perspective. New Phytol 154:267-270

Pregitzer K, King J, Burton A, Brown S (2000) Responses of tree fine roots to temperature. New Phytol 147:107-115
Prislan P, Gričar J, de Luis M et al (2013) Phenological variation in xylem and phloem formation in Fagus sylvatica from two contrasting sites. Agric For Meteorol 180:142-151. doi:10.1016/j.agrformet.2013.06. 001

Puhe J (2003) Growth and development of the root system of Norway spruce (Picea abies) in forest stands: a review. For Ecol Manag 175: 253-273

Quan X, Wang C, Zhang Q et al (2010) Dynamics of fine roots in five Chinese temperate forests. J Plant Res 123:497-507. doi:10.1007/ s10265-010-0322-9

Rathgeber CBK, Longuetaud F, Mothe F et al (2011a) Phenology of wood formation: data processing, analysis and visualisation using R (package CAVIAR). Dendrochronologia 29:139-149. doi:10. 1016/j.dendro.2011.01.004

Rathgeber CBK, Rossi S, Bontemps J-D (2011b) Cambial activity related to tree size in a mature silver-fir plantation. Ann Bot 108:429-438. doi:10.1093/aob/mcr168

Réaumur R-A (1735) Observations du thermomètre faites à Paris pendant l'année 1735, comparées avec celles qui ont été faites sous la ligne, à l'Isle de France, à Alger et quelques unes de nos iles de l'Amérique. Mémoires l'Académie R des Sci 545-576

Richardson AD, Anderson RS, Arain MA et al (2012) Terrestrial biosphere models need better representation of vegetation phenology: results from the North American Carbon Program Site Synthesis. Glob Chang Biol 18:566-584. doi:10.1111/j.1365-2486.2011. 02562.x

Richardson AD, Keenan TF, Migliavacca M et al (2013) Climate change, phenology, and phenological control of vegetation feedbacks to the climate system. Agric For Meteorol 169:156-173. doi:10.1016/j. agrformet.2012.09.012

Rinne PLH, Kaikuranta PM, Van Der Schoot C (2001) The shoot apical meristem restores its symplasmic organization during chillinginduced release from dormancy. Plant J 26:249-264. doi:10.1046/ j.1365-313X.2001.01022.x

Rohde A, Bastien C, Boerjan W (2011) Temperature signals contribute to the timing of photoperiodic growth cessation and bud set in poplar. Tree Physiol 31:472-482. doi:10.1093/treephys/tpr038

Rossi S, Anfodillo T, Cufar K et al (2013) A meta-analysis of cambium phenology and growth: linear and non-linear patterns in conifers of the northern hemisphere. Ann Bot 112:1911-1920. doi:10.1093/ aob/mct243

Rossi S, Deslauriers A, Anfodillo T et al (2006) Conifers in cold environments synchronize maximum growth rate of tree-ring formation with day length. New Phytol 170:301-310

Rossi S, Deslauriers A, Griçar J et al (2008) Critical temperatures for xylogenesis in conifers of cold climates. Glob Ecol Biogeogr 17: 696-707. doi:10.1111/j.1466-8238.2008.00417.x

Rossi S, Morin H, Deslauriers A (2012) Causes and correlations in cambium phenology: towards an integrated framework of xylogenesis. $\mathrm{J}$ Exp Bot 63:2117-2126. doi:10.1093/jxb/err423

Rossi S, Morin H, Deslauriers A, Plourde P-Y (2011) Predicting xylem phenology in black spruce under climate warming. Glob Chang Biol 17:614-625. doi:10.1111/j.1365-2486.2010.02191.x

Rossi S, Rathgeber CBK, Deslauriers A (2009) Comparing needle and shoot phenology with xylem development on three conifer species in Italy. Ann For Sci 66:1-8

Rötzer T, Chmielewski F-M (2001) Phenological maps of Europe. Clim Res 18:249-257

Rötzer T, Grote R, Pretzsch H (2004) The timing of bud burst and its effect on tree growth. Int J Biometeorol 48:109-118. doi:10.1007/ s00484-003-0191-1

Saffell BJ, Meinzer FC, Woodruff DR et al (2014) Seasonal carbohydrate dynamics and growth in Douglas-fir trees experiencing chronic, fungal-mediated reduction in functional leaf area. Tree Physiol 34: 218-228. doi:10.1093/treephys/tpu002 
Salifu KF, Timmer VR (2003) Optimizing nitrogen loading of Picea mariana seedlings during nursery culture. Can J For Res 33:12871294

Salminen H, Jalkanen R (2007) Intra-annual height increment of Pinus sylvestris at high latitudes in Finland. Tree Physiol 27:1347-1353

Sanz-Pérez V, Castro-Díez P (2010) Summer water stress and shade alter bud size and budburst date in three Mediterranean Quercus species. Trees 24:89-97

Sarvas R (1974) Investigations on the annual cycle of development of forest trees. II. Autumn dormancy and winter dormancy. Commun Inst For Fenn 84:101

Sarvas R (1972) Investigations on the annual cycle of development of forest trees. 1. Active period. Commun Inst For Fenn 76:110

Sass-Klaassen U, Sabajo CR, den Ouden J (2011) Vessel formation in relation to leaf phenology in pedunculate oak and European ash. Dendrochronologia 29:171-175. doi:10.1016/j.dendro.2011.01.002

Schaber J, Badeck FW (2005) Plant phenology in Germany over the 20th century. Reg Environ Chang 5:37-46. doi:10.1007/s10113-0040094-7

Schenker G, Lenz A, Körner C, Hoch G (2014) Physiological minimum temperatures for root growth in seven common European broadleaved tree species. Tree Physiol 34:302-313. doi:10.1093/ treephys/tpu003

Schiestl-Aalto P, Kulmala L, Harri M (2015) CASSIA - a dynamic model for predicting intra-annual sink demand and interannual growth variation in Scots pine. New Phytol. doi:10.1111/nph.13275

Schrader J, Baba K, May ST et al (2003) Polar auxin transport in the wood-forming tissues of hybrid aspen is under simultaneous control of developmental and environmental signals. Proc Natl Acad Sci U S A 100:10096-10101. doi:10.1073/pnas.1633693100

Sedgley M, Griffin A (1989) Sexual reproduction of tree crops. 392 pp

Seo J-W, Eckstein D, Jalkanen R et al (2008) Estimating the onset of cambial activity in Scots pine in northern Finland by means of the heat-sum approach. Tree Physiol 28:105-112. doi:10.1093/ treephys/28.1.105

Sharp WM, Spargue VG (1967) Flowering and fruiting in the white oaks. Pistillate flowering, acorn development, weather and yields. Ecology 243-251

Shishkova S, Rost TL, Dubrovsky JG (2008) Determinate root growth and meristem maintenance in angiosperms. Ann Bot 101:319-340. doi:10.1093/aob/mcm251

Smart BYCM (1994) Gene expression during leaf senescence. New Phytol 126:419-448

Sparks T, Carey P (1995) The responses of species to climate over two centuries: an analysis of the Marsham phenological record, 17361947. J Ecol 83:321-329

Srivastava L (2002) Plant growth and development: hormones and environment. 772

Staswick PE (1994) Storage proteins of vegetative plant tissues. Annu Rev Plant Physiol Plant Mol Biol 45:303-322

Sudachkova NE, Milyutina IL, Romanova LI, Semenova GP (2004) The annual dynamics of reserve compounds and hydrolitic enzymes activity in the tissues of Pinus sylvestris L. and Larix sibirica Ledeb.the metabolism of reserve compounds in the tissues of Siberian conifers. Eur J For Res 7:1-10

Suzuki M, Yoda K, Suzuki H (1996) Phenological comparison of the onset of vessel formation between ring-porous and diffuse-porous deciduous trees in a Japanese temperate forest. IAWA J 17:431-444

Takahashi K, Koike S (2014) Altitudinal differences in bud burst and onset and cessation of cambial activity of four subalpine tree species. Landsc Ecol Eng 10:349-354. doi:10.1007/s11355-014-0250-2

Takahashi S, Okada N, Nobuchi T (2013) Relationship between the timing of vessel formation and leaf phenology in ten ring-porous and diffuse-porous deciduous tree species. Ecol Res 28:615-624. doi:10.1007/s11284-013-1053-x
Tanino KK, Kalcsits L, Silim S et al (2010) Temperature-driven plasticity in growth cessation and dormancy development in deciduous woody plants: a working hypothesis suggesting how molecular and cellular function is affected by temperature during dormancy induction. Plant Mol Biol 73:49-65. doi:10.1007/s11103-0109610-y

Teskey R, Hinckley T (1981) Influence of temperature and water potential on root growth of white oak. Physiol Plant 52:363-369

Thibeault-Martel M, Krause C, Morin H, Rossi S (2008) Cambial activity and intra-annual xylem formation in roots and stems of Abies balsamea and Picea mariana. Ann Bot 102:667-674. doi:10. 1093/aob/men146

Tikkanen O-P, Julkunen-Tiitto R (2003) Phenological variation as protection against defoliating insects: the case of Quercus robur and Operophtera brumata. Oecologia 136:244-251. doi:10.1007/ s00442-003-1267-7

Tooke F, Battey NH (2010) Temperate flowering phenology. J Exp Bot 61:2853-2862. doi:10.1093/jxb/erq165

Ursino DJ, Nelson CD, Krotkov G (1968) Seasonal changes in the distribution of photo-assimilated $14 \mathrm{C}$ in young pine plants. Plant Physiol 43:845-852

Vaganov EA, Hughes MK, Shashkin AV (2006) Modeling external influence on xylem development. Ecol Stud 183:189-243

Valenzuela Nuñez LM, Gérant D, Maillard P et al (2011) Evidence for a $26 \mathrm{kDa}$ vegetative storage protein in the stem sapwood of mature pedunculate oak. Interciencia 36:142-147

Valenzuela Nuñez LM, Gérant D, Maillard P, Bréda N (2010) Seasonal dynamics of total soluble proteins in adult trees of Quercus petraea (Matt.) Liebl. and Fagus sylvatica L. Rev Mex Ciencias For 1:7583

Visser ME, Holleman LJ (2001) Warmer springs disrupt the synchrony of oak and winter moth phenology. Proc Biol Sci 268:289-294. doi:10. 1098/rspb.2000.1363

Visser ME, Holleman LJM, Gienapp P (2006) Shifts in caterpillar biomass phenology due to climate change and its impact on the breeding biology of an insectivorous bird. Oecologia 147:164-172. doi: 10.1007/s00442-005-0299-6

Vitasse Y (2013) Ontogenic changes rather than difference in temperature cause understory trees to leaf out earlier. New Phytol 198:149-155. doi:10.1111/nph.12130

Vitasse Y, Basler D (2013) What role for photoperiod in the bud burst phenology of European beech. Eur J For Res 132:1-8. doi:10.1007/ s10342-012-0661-2

Vitasse Y, Basler D (2014) Is the use of cuttings a good proxy to explore phenological responses of temperate forests in warming and photoperiod experiments? Tree Physiol 34:174-183. doi:10.1093/ treephys/tpt116

Vitasse Y, François C, Delpierre N et al (2011) Assessing the effects of climate change on the phenology of European temperate trees. Agric For Meteorol 151:969-980. doi:10.1016/j.agrformet.2011.03.003

Vitasse Y, Hoch G, Randin CF et al (2013) Elevational adaptation and plasticity in seedling phenology of temperate deciduous tree species. Oecologia 171:663-678. doi:10.1007/s00442-012-2580-9

Vitasse Y, Porté AJ, Kremer A et al (2009) Responses of canopy duration to temperature changes in four temperate tree species: relative contributions of spring and autumn leaf phenology. Oecologia 161:187198. doi:10.1007/s00442-009-1363-4

Wang S, Grant R, Verseghy D, Black T (2001) Modelling plant carbon and nitrogen dynamics of a boreal aspen forest in CLASS - the Canadian Land Surface Scheme. Ecol Model 142:135-154. doi: 10.1016/S0304-3800(01)00284-8

Wang YP, Law RM, Pak B (2010) A global model of carbon, nitrogen and phosphorus cycles for the terrestrial biosphere. Biogeosciences 7: 2261-2282. doi:10.5194/bg-7-2261-2010 
Wareing PF, Saunders PF (1971) Hormones and dormancy. Annu Rev Plant Physiol 22:261-288. doi:10.1146/annurev.pp. 22.060171. 001401

Way DA (2011) Tree phenology responses to warming: spring forward, fall back? Tree Physiol 31:469-471. doi:10.1093/treephys/tpr044

Way D, Montgomery R (2014) Photoperiod constraints on tree phenology, performance and migration in a warming world. Plant Cell Environ 1-48. doi: 10.1111/pce.12431

Weinberger JH (1950) Chilling requirements of peach varieties. Proc Am Soc Hortic Sci 56:122-128

White MA, Running SW, Thornton PE (1999) The impact of growingseason length variability on carbon assimilation and evapotranspiration over 88 years in the eastern US deciduous forest. Int $\mathrm{J}$ Biometeorol 42:139-145. doi:10.1007/s004840050097

White MA, Thornton PE, Running SW (1997) A continental responses phenology model climatic for monitoring variability vegetation to interannual. Glob Biogeochem Cycles 11:217-234

Wiley E, Huepenbecker S, Casper BB, Helliker BR (2013) The effects of defoliation on carbon allocation: can carbon limitation reduce growth in favour of storage? Tree Physiol 33:1216-1228. doi:10. 1093/treephys/tpt093

Wilson B (1984) The growing tree. 138 pp
Wilson B, Wodzicki T, Zahner R (1966) Notes: differentiation of cambial derivatives: proposed terminology. For Sci 12:438-440

Wilson KB, Baldocchi DD (2000) Seasonal and interannual variability of energy fluxes over a broadleaved temperate deciduous forest in North America. Agric For Meteorol 100:1-18. doi:10.1016/ S0168-1923(99)00088-X

Yang X, Mustard JF, Tang J, Xu H (2012) Regional-scale phenology modeling based on meteorological records and remote sensing observations. J Geophys Res 117:G03029. doi:10.1029/ 2012JG001977

Yin X, Kropff MJ, McLaren G, Visperas RM (1995) A nonlinear model for crop development as a function of temperature. Agric For Meteorol 77:1-6

Yoshie F, Sakai A (1982) Freezing resistance of temperate deciduous forest plants in relation to their life form and microhabitat. In: $\mathrm{Li}$ PH, Sakai A (eds) Plant cold hardiness. Freez. Stress - Mech. Crop Implic. Academic Press, New York, p 686

Zaehle S, Friend A (2010) Carbon and nitrogen cycle dynamics in the O$\mathrm{CN}$ land surface model: 1 . Model description, site-scale evaluation, and sensitivity to parameter estimates. Glob Biogeochem Cycles. doi:10.1029/2009GB003522

Zeeman SC, Smith SM, Smith AM (2007) The diurnal metabolism of leaf starch. Biochem J 401:13-28. doi:10.1042/BJ20061393 